OPEN ACCESS

Edited by:

Julie Lucifora,

Institut National de la Santé et de la Recherche Médicale (INSERM),

France

Reviewed by:

Yuchen Xia,

Wuhan University, China

Barbara Testoni,

Institut National de la Santé et de la

Recherche Médicale (INSERM),

France

Gregor Ebert,

Technical University of Munich,

Germany

*Correspondence:

Ellen Van Damme

EVANDAMM@its.jnj.com

${ }^{\dagger}$ These authors have contributed equally to this work and share first

authorship

Specialty section

This article was submitted to

Virology,

a section of the journal

Frontiers in Microbiology

Received: 14 June 2021

Accepted: 17 August 2021

Published: 16 September 2021

Citation:

Van Damme E, Vanhove J,

Severyn $B$, Verschueren $L$ and

Pauwels $F$ (2021) The Hepatitis $B$ Virus Interactome: A Comprehensive

Overview.

Front. Microbiol. 12:724877. doi: 10.3389/fmicb.2021.724877

\section{The Hepatitis B Virus Interactome: A Comprehensive Overview}

\author{
Ellen Van Damme ${ }^{1 * \dagger}$, Jolien Vanhove ${ }^{1,2+}$, Bryan Severyn $^{3}$, Lore Verschueren ${ }^{1}$ and \\ Frederik Pauwels ${ }^{1}$
}

1 Janssen Research \& Development, Janssen Pharmaceutical Companies, Beerse, Belgium, ${ }^{2}$ Early Discovery Biology, Charles River Laboratories, Beerse, Belgium, ${ }^{3}$ Janssen Research \& Development, Janssen Pharmaceutical Companies, Springhouse, PA, United States

Despite the availability of a prophylactic vaccine, chronic hepatitis $\mathrm{B}(\mathrm{CHB})$ caused by the hepatitis B virus (HBV) is a major health problem affecting an estimated 292 million people globally. Current therapeutic goals are to achieve functional cure characterized by HBsAg seroclearance and the absence of HBV-DNA after treatment cessation. However, at present, functional cure is thought to be complicated due to the presence of covalently closed circular DNA (cccDNA) and integrated HBVDNA. Even if the episomal cccDNA is silenced or eliminated, it remains unclear how important the high level of HBsAg that is expressed from integrated HBV DNA is for the pathology. To identify therapies that could bring about high rates of functional cure, in-depth knowledge of the virus' biology is imperative to pinpoint mechanisms for novel therapeutic targets. The viral proteins and the episomal cccDNA are considered integral for the control and maintenance of the HBV life cycle and through direct interaction with the host proteome they help create the most optimal environment for the virus whilst avoiding immune detection. New HBV-host protein interactions are continuously being identified. Unfortunately, a compendium of the most recent information is lacking and an interactome is unavailable. This article provides a comprehensive review of the virushost relationship from viral entry to release, as well as an interactome of cccDNA, HBc, and $\mathrm{HBx}$.

\section{Keywords: hepatitis B virus, interactome, viral-host life cycle, cccDNA, HBx, HBc}

\section{INTRODUCTION}

Hepatitis B virus (HBV) is a member of the Hepadnaviridae family which is transmitted via bodily fluids as well as by vertical transmission (Davis et al., 1989; Schweitzer et al., 2015). The outcome of HBV infection is determined by multiple host and viral factors, and determines whether the infection will be acute, chronic, or occult (Fanning et al., 2019). Despite the availability of a prophylactic vaccine and potent antiviral treatments, chronic hepatitis B (CHB) infection affects 292 million individuals worldwide (Lazarus et al., 2018). The current standard of care is treatment with nucleos(t)ide analogs (NUCs) (i.e., lamivudine, adefovir, entecavir, telbivudine, and tenofovir), that inhibit the HBV polymerase reverse transcription (Liang et al., 2015). These therapies lead to suppression of viral replication, visible by a decrease in viral load, the normalization of serum alanine transaminase and improvement of liver histology 
(Bitton Alaluf and Shlomai, 2016). However, even prolonged treatment with NUCs rarely results $(<10 \%)$ in functional cure of $\mathrm{CHB}$ and most often leads to virological relapse after treatment cessation (Liang et al., 2015; Kim, 2018).

Also pegylated interferon alpha (peg-IFN $\alpha$ ) is approved for use in $\mathrm{CHB}$ patients although it is not the preferred therapy due to the occurrence of side effects. Furthermore, it is counter indicated for some patients such as those with liver cirrhosis (Saracco et al., 1994).

Untreated or off-treatment chronic patients are at risk to develop life threatening conditions such as fibrosis, cirrhosis, liver failure, and hepatocellular carcinoma (HCC). In 2015, 887,000 people died from HBV-related cirrhosis and liver cancer alone (WHO, 2017). The ultimate therapeutic goal in $\mathrm{CHB}$ is preventing these life-limiting outcomes and to achieve a functional cure characterized by the loss of surface antigen (HBsAg) and HBV-DNA in the blood off-treatment.

Hepatitis B virus functional cure will be achieved when the high viral load, the antigen burden and inadequate host immune responses are overcome and thus may need a broader therapeutic approach involving multiple targets, both viral and host. With regard to the latter, in-depth knowledge of the HBV life cycle is indispensable for identifying mechanisms, that are targetable with new therapeutics.

Part of the therapeutic approach may be to target the interface between viral proteins and cellular targets. The HBV viral proteins have pluripotent functions and our understanding of how they interact with host proteins is continuously evolving. The interactions of these viral factors with the host cell proteome are complex and helps to shape the cellular environment for the virus to replicate. In addition, cccDNA, the template of all viral mRNAs, behaves as a minichromosome and attracts a multitude of protein partners. However, all these reported interactions are scattered in literature, and currently there is no overview bringing together the interactome of HBV. This review aims to provide such an overview, from entry to viral release, it summarizes the known interactions between viral proteins and host proteins. Because cccDNA, $\mathrm{HBc}$, and $\mathrm{HBx}$ have been described in many interactions, we focused the construction of an interactome network around these three entities.

\section{INTERACTIONS DURING THE EARLY PHASES OF HBV INFECTION}

The HBV particle consists of an incomplete $3.2 \mathrm{~kb}$ doublestranded (ds)DNA genome [relaxed circular DNA (RC-DNA)] packaged together with the viral polymerase in an icosahedral capsid assembled by HBV core (HBc) proteins (Summers et al., 1975). This nucleocapsid is enveloped by a lipid membrane studded with three forms of $\mathrm{HBV}$ surface antigen protein (collectively referred to as $\mathrm{HBsAg}$ ) to compose the virus or Dane particle [reviewed by Bruss (2004)].

The life cycle of HBV begins upon its interaction with heparan sulfate proteoglycans (HSPGs) and subsequent binding to the sodium taurocholate co-transporting polypeptide (NTCP) receptor on the surface of the hepatocyte (Watashi et al., 2014;
Yan et al., 2014; Figure 1). The interaction between virus and cell induces conformational changes of the membrane embedded myristoylated N-terminal preS1-domain of the viral large surface protein (L-HBsAg) leading to exposure of the receptor binding site for the NTCP receptor, which enables binding of the virus and entrance into the cell (Schulze et al., 2007, 2010; Yan et al., 2012, 2013, 2014; Nkongolo et al., 2014; Watashi et al., 2014). Recently, a crucial role in mediating HBV-NTCP internalization of epidermal growth factor receptor (EGFR) was published (Iwamoto et al., 2019). Besides the NTCP receptor, squamous cell carcinoma antigen 1 (SCCA1) and ferritin light chain (FTL) have also been identified as HBV co-receptors (Figure 1). Triple complexes of preS1, FTL, and SCCA1 were observed and overexpression assays with these proteins showed increased infection rates both in vitro and in vivo (Hao et al., 2012). The prevention of entry has been of interest as an antiviral target to circumvent viral spread by blocking de novo infection. In recent years molecules such as Myrcludex B (also known as bulevirtide), ezetimibe, cyclosporin derivates (CsA), and monoclonal antibodies against HBsAg epitopes were identified to interfere with this process (Gripon et al., 2005; Lucifora et al., 2013; Shimura et al., 2017).

The virus enters the cell by inducing endocytosis via caveolinmediated endocytosis or via clathrin-mediated pathways (Macovei et al., 2010; Umetsu et al., 2018; Figure 1). In differentiated HepaRG cells, HBV infection has shown to be dependent on caveolin-mediated endocytosis. However, in Umetsu et al. (2018), the formation of a complex between the L-HBsAg, the clathrin heavy chain (CHC) and the clathrin adaptor protein-2 (AP-2) was described, suggesting an alternative endocytosis pathway (Figure 1). Indeed, inhibition of the clathrin-mediated pathway by silibinin and chlorpromazine has been reported to impair HBV uptake (Huang et al., 2012). Further work will be needed to understand the relative importance of these two pathways. After endocytosis, subsequent movement of the virus through the endocytic pathway is regulated by Rab proteins. These are guanosine triphosphatases (GTPases) that occupy specific endocytic compartments and direct endocytic vesicles to different cellular compartments. Silencing of Rab5 or Rab7, in contrast with Rab9 and Rab11, resulted in the inhibition of the early stages of HBV infection implying that the transport of virus to late endosomes is important for a successful infection (Macovei et al., 2013; Figure 1).

The precise location and timing of nucleocapsid release from the envelope remains unclear, but this process is required prior to nuclear entry. Transport of the nucleocapsid to the nucleus is facilitated by the microtubule network and the dynein L11 motor proteins through a direct interaction with the capsid (Osseman et al., 2018; Figure 1). In the nucleocapsid "uncoating" process, phosphorylation of the C-terminus of $\mathrm{HBc}$ destabilizes the capsid and allows the binding of importins $\alpha$ and $\beta$ (Kann et al., 1999; Barrasa et al., 2001; Nguyen et al., 2008). Although a direct interaction has not been established, a number of kinases including core associated kinase (CAK), SR protein-specific kinase 1 (SRPK1) and SR protein-specific kinase 2 (SRPK2), have been reported to be involved in this phosphorylation process (Kau and Ting, 1998; Daub et al., 2002; Figure 1). 


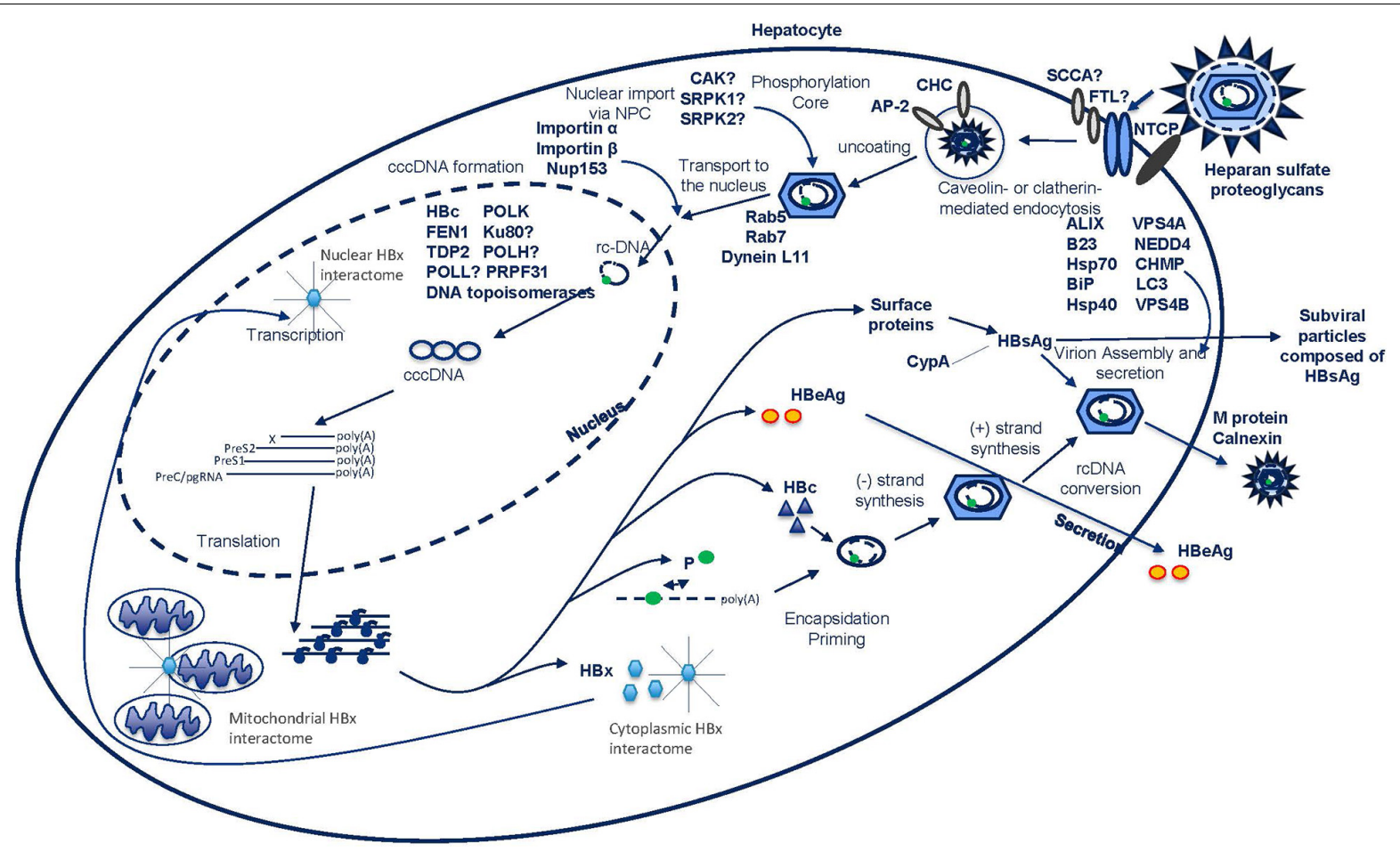

FIGURE 1 | HBV life cycle from viral entry to release.

Once the nucleocapsid arrives at the nuclear pore complex (NPC), it can pass the complex as an intact particle (Pante and Kann, 2002; Fay and Pante, 2015). Interestingly, HBV seems to utilize a unique way of triaging immature from mature capsids at the level of the NPC as only mature capsids disassemble. In this process, importin $\beta$ and Nup153 play a role via direct interaction with the capsid (Schmitz et al., 2010; Figure 1). Once through the NPC, the capsid is deposited in the nuclear basket where only mature capsids can pass. In the nucleus, the final uncoating, where capsid structures and viral DNA separate, takes place in an importin $\alpha$ and $\beta$-dependent manner (Gallucci and Kann, 2017).

\section{THE cccDNA MINICHROMOSOME}

Once inside the nucleus, the RC-DNA is converted into cccDNA (Summers et al., 1975; Tuttleman et al., 1986; Wu et al., 1990; Lieberman, 2016). Early research using duck hepatitis B virus (DHBV) showed that the cccDNA was in fact organized as a minichromosome similar to host chromatin and SV40 (Newbold et al., 1995). Further DHBV studies showed that in vitro between 1 and 56 copies cccDNA reside in the nuclei of infected cells (Kock et al., 2010). These copy numbers were slightly lower (1-17 copies/cell) in in vivo studies in ducks. Further it was determined that the half-life of DHBV cccDNA is between 35 and 57 days (Addison et al., 2002; Zhang et al., 2003) although shorter half-lives have described (Tuttleman et al., 1986; Wu et al., 1990; Newbold et al., 1995). In vitro kinetic studies were also done using $\mathrm{HBV}$, cccDNA formation is an early life cycle event (Tuttleman et al., 1986) and it was shown that the cccDNA pool grows over the course of 3 days after which a stable pool is reached (5-12 copies/cell) with a half-life of about 40 days (Ko et al., 2014). Similar findings were done using woodchuck HBV (Dandri et al., 2000). Patient samples of HBV infected individuals showed that cccDNA copy numbers were much lower in vivo ranging from 0.01 to 9 copies/cell but at the same time had a much longer half-life of months to a year (Werle-Lapostolle et al., 2004; Bourne et al., 2007; Boyd et al., 2016; Huang et al., 2021). Interestingly, the size and half-life of the cccDNA pool in patients has been suggested to depend on the antigen status (Lythgoe et al., 2021) as much more cccDNA has been shown in HBeAg positive patients while only 0.002 copies/cell were observed in patients that showed HBsAg seroclearance (Werle-Lapostolle et al., 2004).

The cccDNA genome is transcribed to different viral RNAs coding for $\mathrm{HBx}$ (0.7-kb RNA), three forms of HBsAg (2.4-kb RNA encoding the large and 2.1-kb RNA encoding the middle and small $\mathrm{HBsAg}$ ), pre-core protein or $\mathrm{HBeAg}$ (3.5-kb RNA) and the core and polymerase protein (pre-genomic RNA or pgRNA, 3.5-kb). This pgRNA also becomes incorporated in the nucleocapsid thereby providing the template for the viral polymerase to produce RC-DNA.

\section{Host Factors Involved in cccDNA Formation}

Little is known about the host factors involved in the formation of the cccDNA. The L-HBsAg is not directly involved in cccDNA formation, but is part of a negative feedback mechanism 
in which high levels of surface protein shut down nuclear shuttling of mature nucleocapsids and direct the cell to produce virions instead (Summers et al., 1990). HBc is suggested to be present during the cccDNA formation process (Kock et al., 2010; Schreiner and Nassal, 2017) which is further evidenced by the fact that capsid modifiers inhibit cccDNA formation (Berke et al., 2017).

Several host factors have been reported to interact with HBV cccDNA during its formation and have quite diverse roles. The Flap endonuclease 1 (FEN1), an endonuclease that plays a role in DNA replication and repair, was shown to interact with RCDNA in the nucleus and additionally could promote cccDNA formation in vitro (Kitamura et al., 2018; Figure 1). The discovery of a protein partner involved in DNA damage repair is coherent with the previous finding that this machinery is exploited by viruses to their own benefit (Schreiner and Nassal, 2017). Ku80, a component of non-homologous end joining DNA repair pathway, was essential for synthesis of cccDNA from dsDNA, but not from RC-DNA (Guo et al., 2012; Figure 1). In these processes, $\mathrm{HBx}$ could be an adaptor to link cccDNA formation with DNA damage response pathways, under the assumption that $\mathrm{HBx}$ is already present in the cell when cccDNA is being formed (Hodgson et al., 2012; Guo et al., 2014; Murphy et al., 2016; Niu C. et al., 2017). The link with the host DNA damage and repair machinery does not end with this interaction, the tyrosyl-DNA-phosphodiesterase (TDP2) also plays a partial role in cccDNA formation by releasing the viral transcriptase from the RC-DNA (Koniger et al., 2014; Cui et al., 2015; Figure 1). The host DNA polymerases K (POLK), H (POLH), and L (POLL) have all been reported to have a positive impact on cccDNA formation, however, the exact mechanism(s) is (are) not yet clear (Qi et al., 2016; Figure 1). In addition to DNA polymerases, knockout experiments showed the importance of cellular DNA ligase 1 and 2 in cccDNA formation (Long et al., 2017). Recently, it was shown that the plus-strand and the minus-strand require different cellular proteins. The plus-strand repair required proliferating cell nuclear antigen (PCNA), replication factor C (RFC) complex, DNA polymerase delta (POL $\delta$ ), flap endonuclease 1 (FEN1), and DNA ligase 1 (LIG1) while the repair of the minus-strand only required FEN1 and LIG1 (Wei and Ploss, 2020). Also cellular DNA topoisomerases are required for cccDNA formation and amplification (Sheraz et al., 2019). Finally, pre-mRNA processing factor 31 (PRPF31) was identified as a cccDNA-associating factor involved in cccDNA formation (Kinoshita et al., 2017; Figure 1).

\section{The Interactome of the cccDNA}

Similar to a cellular chromosome, the cccDNA is bound to histones to form a minichromosome. These host-derived histones ( $\mathrm{H} 2 \mathrm{~A}, \mathrm{H} 2 \mathrm{~B}, \mathrm{H} 3$, and $\mathrm{H} 4)$ provide, together with the viral $\mathrm{HBc}$, the stable scaffold for the cccDNA to be supercoiled (Newbold et al., 1995; Chong et al., 2017). That being said, the role of $\mathrm{HBc}$ in both cccDNA formation and maintenance is still under investigation. For example, despite their involvement in several processes regarding cccDNA formation, maintenance and transcription, capsid modifying compounds do not eliminate the cccDNA pool (Berke et al., 2017) nor is $\mathrm{HBc}$ essential for transcription (Zhang et al., 2014).
On the cccDNA of Duck hepatitis B virus (DHBV), nucleosomes are non-randomly positioned, suggesting that, like host cellular chromatin, positioning of the nucleosomes and histone modifications of the cccDNA may regulate cccDNA transcription (Bock et al., 1994; Pollicino et al., 2006). Methylation, acetylation, phosphorylation or other posttranslational modifications (PTMs) of these cccDNA-bound histone tails can fine tune the gene expression by altering the chromatin structure (Tropberger et al., 2015). This change in structure can wind the chromatin more tightly to prevent access of transcription factors and repress gene transcription. On the other hand, histone modifications can also result in increased DNA accessibility, transcription factor binding and therefore promoting gene activation (Li et al., 2007; Voss and Hager, 2014). In addition, the minichromosome attracts several other partners, many of which are transcription factors that further determine whether the cccDNA is transcriptionally active or inactive (Table 1).

As previously mentioned, $\mathrm{HBx}$ and $\mathrm{HBc}$ proteins are bound to cccDNA. HBc has been described to modulate transcription from the cccDNA. Zlotnick et al. showed that the presence of $\mathrm{HBc}$ on a $\mathrm{CpG}$ island in the cccDNA can be linked to increased cccDNA activity, while methylation of the $\mathrm{CpG}$ island correlated with decreased cccDNA activity (Zlotnick et al., 2015). In addition, the presence of $\mathrm{HBc}$ appears to have a role in the maintenance of the structure of the cccDNA (Bock et al., 2001). Together these data suggest that $\mathrm{HBc}$ contributes to the epigenetic regulation of the cccDNA, which in turn contributes to its longevity.

\section{Modalities Acting on cccDNA}

A role in viral rebound made cccDNA a target for new antiviral drug development. Success of such tactics relies on complete inhibition of cccDNA throughout the lifespan of the hepatocyte. A first approach is to target the formation of cccDNA, although it can be questioned how much benefit $\mathrm{CHB}$ patients will have of such a therapy in the event the cccDNA does not become reduced. Several molecules reported to act through this mechanism have been described in literature. However, to date, these molecules have either been stopped at pre-clinical stage or did not progress far in clinical trials (Cai et al., 2012; Liu et al., 2016). The only assets which encompass this capacity and are still under clinical investigation are the entry inhibitor bulevirtide and capsid assembly modulators. The latter are small molecules that accelerate capsid formation but turned out to have a dual mode of action in preventing cccDNA formation when added in vitro at early stages of infection (Berke et al., 2017; Vandenbossche et al., 2019). Secondly, a number of molecules have been described that silence the cccDNA, either by inhibiting cccDNA transcription [e.g., Tamibarotene (Nkongolo et al., 2019)] or by diminishing HBV RNA levels post-transcription (e.g., RNA destabilizers such as RG7834 (Mueller et al., 2019); RNA interference). Tamibarotene never made it to clinical trials for HBV, while RG7834 was stopped in Phase I. Transcriptional control of cccDNA expression may also be achieved by interfering with the function of $\mathrm{HBx}, \mathrm{HBc}$ or an interaction partner. An example is the interference between $\mathrm{HBx}$ and DNA damagebinding protein 1 (DDB1). HBx was found to hijack DDB1 
TABLE 1 | List of known protein-cccDNA interactions associated with increased or decreased transcriptional regulation.

\begin{tabular}{|c|c|c|}
\hline $\begin{array}{l}\text { cccDNA minichromosome } \\
\text { partner }\end{array}$ & Process & References \\
\hline
\end{tabular}

\begin{tabular}{|c|c|}
\hline \multicolumn{2}{|c|}{ Associated with Enhanced Replication - Verified Interactions } \\
\hline $\mathrm{HBx}$ & Required for replication and transcription. \\
\hline $\mathrm{HBC}$ & $\mathrm{HBc}$ binds to the $\mathrm{CpG}$ islands of HBV cccDNA. \\
\hline $\mathrm{CBP}$ & $\begin{array}{l}\text { HBx interacts and cooperates with CBP to modify chromatin dynamics and enhances CREB } \\
\text { activity. }\end{array}$ \\
\hline P300 & HBx increases amount of P300 recruited to promotors. \\
\hline PCAF & Recruited to the cccDNA after HBx binding to the minichromosome. \\
\hline LSD1/KDM1A & $\begin{array}{l}\text { Recruited in an HBx-dependent manner, induces HBV replication and HBV transcription involves } \\
\text { the demethylation of histone } 3 \text { lysine } 9(\mathrm{H} 3 \mathrm{~K} 9) \text {. }\end{array}$ \\
\hline CREB/CREB1 & $\begin{array}{l}\text { Essential for HBV replication. It binds to the cAMP response elements (CREs) located at the } \mathrm{X} \text { and } \\
\text { preS2 promoters. Interaction with ccCDNA dependent on CRTC1. }\end{array}$ \\
\hline STAT1 & Binds to cccDNA, binding impaired upon IFN treatment. \\
\hline STAT2 & Binds to cccDNA, binding impaired upon IFN treatment. \\
\hline STAT3 & May bind to enhancer I (ENI) and increase function. \\
\hline Set1A/SETD1A & $\begin{array}{l}\text { Recruited via a HBx-dependent manner, stimulates an active cccDNA epigenetic state by } \\
\text { methylating histone } 3 \text { lysine } 4(\mathrm{H} 3 \mathrm{~K} 4) \text { in viral HBV promoters. }\end{array}$ \\
\hline CRTC1 & $\begin{array}{l}\text { Recruited to the preS2/S promotor for the activation of replication. Interaction with cccDNA } \\
\text { dependent on CREB/CREB1. }\end{array}$ \\
\hline KLF15 & Activates S and HBc promotors and enhances replication when overexpressed. \\
\hline SIRT1 & $\begin{array}{l}\text { SIRT1 interacts with } \mathrm{HBx} \text { and promotes the recruitment of } \mathrm{HBx} \text { and other transcriptional factors to } \\
\text { the cccDNA (specifically to the precore promoter), promoting the activation of HBV transcription } \\
\text { (Deng et al., 2017). However, after IFN } \alpha \text { treatment, SIRT1 is recruited to the cccDNA to repress } \\
\text { transcription. }\end{array}$ \\
\hline RFX1 & Binds the enhancer region upon doxorubicin treatment to promote replication. \\
\hline $\mathrm{RXR} \alpha$ & $\mathrm{RXR} \alpha$ recruitment to the cccDNA in parallel with P300 recruitment \\
\hline SP1 & Several binding sites, depending on the site, the activity of SP1 is enhancing or inhibitory. \\
\hline TBP & Binds the TATA box. \\
\hline NRF1 & Binds to the $\mathrm{HBx}$ promotor and positively regulates $\mathrm{HBx}$ transcription \\
\hline C/EBP & $\begin{array}{l}\text { Binds enhancer II (Enhll) and the HBc promotor. Low concentrations have a positive effect on } \\
\text { replication while high concentrations evoke inhibition. Potentially also a repressor role. }\end{array}$ \\
\hline PPAR & Increases transcription from several promotors. \\
\hline $\mathrm{FXR} / \mathrm{NR} 1 \mathrm{H} 4$ & Can bind Enhll and $\mathrm{HBC}$ regions to have a stimulating effect on transcription. \\
\hline AP1 & Binding to HBc promotor and shown to work in synergy with SIRT and HBX. \\
\hline
\end{tabular}

HNF1/HNF1A

$\mathrm{LRH}-1(\mathrm{NR} 5 \mathrm{~A} 2) / \mathrm{hB} 1 \mathrm{~F}$

HNF3

HNF4/HNF4A

HLF

FTF

Parvulin 14

Parvulin 17

Activation-induced cytidine

deaminase (AID)

P19

Required for replication and transcription.

$\mathrm{HBx}$ interacts and cooperates with CBP to modify chromatin dynamics and enhances CREB activity.

Recruited to the cccDNA after HBx binding to the minichromosome. the demethylation of histone 3 lysine 9 (H3K9). pres2 promoters. Interaction with cccDNA dependent on CRTC1.

May bind to enhancer I (ENI) and increase function.

methylating histone 3 lysine $4(\mathrm{H} 3 \mathrm{~K} 4)$ in viral HBV promoters.

Recruited to the pres2/S promotor for the activation of replication. Interaction with cccDNA

An CREB/CREB 1

SIRT1 interacts with $\mathrm{HBx}$ and promotes the recruitment of $\mathrm{HBx}$ and other transcriptional factors to the cccDNA (specifically to the precore promoter), promoting the activation of HBV transcription transcription

$\mathrm{RXR} \alpha$ recruitment to the cccDNA in parallel with P300 recruitment

Several binding sites, depending on the site, the activity of SP1 is enhancing or inhibitory.

Binds the TATA box.

replication while high concentrations evoke inhibition. Potentially also a repressor role.

Binding to HBc promotor and shown to work in synergy with SIRT and HBx.

Binding sites on the preS promotor. HNF1/HNF1A synergistically works with Oct1 and

$\mathrm{LRH}-1 / \mathrm{NR} 5 \mathrm{~A} 2$ to enhance replication.

Transactivator of the Enhll and HBc regions. Synergy with HNF1/HNF1A.

Several binding sites identified, binding seems to be associated with a stimulating effect.

Stimulation of transcription from several promotors.

Stimulatory effect on the $\mathrm{HBc}$ regulatory region.

Stimulatory effect on Enhll.

Recruited to cccDNA in the presence of $\mathrm{HBx}$ to promote transcriptional activation.

Recruited to cccDNA in the presence of $\mathrm{HBx}$ to promote transcriptional activation.

Interaction enhances cccDNA transcription.

Interaction enhances cccDNA transcription.

eplication - Potential Interactions

CRTC2

PGC1 $\alpha$

NF1
Enhances HBV transcription and replication by inducing PGC1 $\alpha$ expression.

Induction of HBV transcription, potentially via FOXO1.
Belloni et al., 2009

Guo et al., 2011

Pollicino et al., 2006; Belloni

et al., 2009

Belloni et al., 2009

Belloni et al., 2009

Alarcon et al., 2016

Tacke et al., 2005; Kim B.K. et al., 2008; Tang et al., 2014)

Belloni et al., 2012

Belloni et al., 2012

Quarleri, 2014

Alarcon et al., 2016

Tang et al., 2014

Zhou et al., 2011

Belloni et al., 2012

Wang et al., 2018

Zhang Y. et al., 2017

Quasdorff and Protzer, 2010

Quasdorff and Protzer, 2010

Quasdorff and Protzer, 2010

Pei and Shih, 1990; Quasdorff and Protzer, 2010

Quasdorff and Protzer, 2010

Quasdorff and Protzer, 2010

Quasdorff and Protzer, 2010;

Ren et al., 2014

Zhou and Yen, 1991; Cai et al., 2003

Cai et al., 2003; Quasdorff and Protzer, 2010

Cai et al., 2003; Quasdorff and Protzer, 2010

Cai et al., 2003; Quasdorff and Protzer, 2010

Ishida et al., 2000

Ishida et al., 2000

Saeed et al., 2018

Saeed et al., 2018

Qiao et al., 2016

Qiao et al., 2016

Tian et al., 2014

Quasdorff and Protzer, 2010;

Tian et al., 2014

Ori et al., 1994; Quasdorff and Protzer, 2010 
TABLE 1 | (Continued)

\begin{tabular}{|c|c|c|}
\hline $\begin{array}{l}\text { cccDNA } \\
\text { minichromosome } \\
\text { partner }\end{array}$ & Process & References \\
\hline Oct1 & Oct-1 and HNF-1 sites are necessary for liver-specific transcription of the preS1 promoter. & Zhou and Yen, 1991 \\
\hline EFC & Binding site identified in central HBc promotor. & Quarleri, 2014 \\
\hline \multicolumn{3}{|c|}{ Associated with supressed Replication - Verified Interactions } \\
\hline \multirow[t]{2}{*}{ HDAC1 } & Correlated with decline in replication. & Belloni et al., 2009; Levrero et al., 2009 \\
\hline & Actively recruited to the cccDNA under IFN $\alpha$-treatment to repress transcription. & Belloni et al., 2012 \\
\hline YY1 & $\begin{array}{l}\text { Part of the transcriptional repressor complex PRC2. Actively recruited to the cccDNA under IFN } \alpha \\
\text { treatment to repress transcription. }\end{array}$ & Belloni et al., 2012 \\
\hline SETDB1 & Repressing histone deacetylase. & Riviere et al., 2015; Alarcon et al., 2016 \\
\hline $\mathrm{EZH} 2$ & Repression of cccDNA. & Salerno et al., 2020 \\
\hline HP1/CBX1 & $\begin{array}{l}\mathrm{HP} 1 / \mathrm{CBX} 1 \text { proteins are recruited to the cccDNA through interaction with } \mathrm{H} 3 \mathrm{~K} 9 \mathrm{me} 3 \text { and contribute } \\
\text { to transcriptional repression. }\end{array}$ & Riviere et al., 2015 \\
\hline Spindlin 1/SPIN1 & Inhibition of transcription from the cccDNA via epigenetic modulation. & Ducroux et al., 2014 \\
\hline APOBEC3G & May contribute to cccDNA editing. Antiviral effect through DNA and RNA packaging. & Nguyen et al., 2007; Luo et al., 2016 \\
\hline SP1 & Several binding sites, depending on the site the activity of SP1 is enhancing or inhibitory. & Quasdorff and Protzer, 2010 \\
\hline TR4 & Repressing function by inhibition of HNF4A mediated transactivation. Binds the HBc promotor. & Quasdorff and Protzer, 2010 \\
\hline HNF1/HNF1A & $\begin{array}{l}\text { Binding site identified on Enhll. Binding associated with a decline in replication by induction of } \\
\text { NF-кB/NFKB1. }\end{array}$ & $\begin{array}{l}\text { Cai et al., 2003; Dai X. et al., 2014; } \\
\text { Lin et al., } 2017\end{array}$ \\
\hline HNF6 & Inhibits gene expression and replication. & Hao et al., 2015 \\
\hline COUP-TF/NH2F1 & $\begin{array}{l}\text { Overexpression of COUP-TF/NH2F1 led to a decrease in replication via binding on NRRE in the } \\
\text { enhancer and } \mathrm{HBc} \text { regions. }\end{array}$ & Yu and Mertz, 2003 \\
\hline PRMT5 & $\begin{array}{l}\text { PRMT5-mediated histone } \mathrm{H} 4 \text { dimethyl Arg3 (H4R3me2) repressed cccDNA transcription. } \\
\text { PRMT5-H4R3me2 interacted with HBc and the Brg1-based hSWI/SNF chromatin remodeler, which } \\
\text { accounted for the reduced binding of RNA polymerase II to cccDNA. }\end{array}$ & Zhang W. et al., 2017 \\
\hline E4BP4/NFIL3 & Associated with suppression of Enhll. & Ishida et al., 2000 \\
\hline NREBP & Inhibits core promotor activity by binding the NRE. Binding is inhibited by HBx. & Lee et al., 2019 \\
\hline $\mathrm{ZHX} 2$ & Restriction factor that regulates HBV promoter activities and cccDNA modifications. & Xu et al., 2018 \\
\hline \multicolumn{3}{|c|}{ Associated with supressed Replication - Potential Interactions } \\
\hline Prox1 & Interacts with $\mathrm{LRH}-1 / \mathrm{NR} 5 \mathrm{~A} 2$ and downregulates $\mathrm{LRH}-1 / \mathrm{NR} 5 \mathrm{~A} 2$ mediated activation. & Quasdorff and Protzer, 2010 \\
\hline APOBECЗА & $\begin{array}{l}\text { Upregulation by IFN } \alpha \text { and lymphotoxin- } \beta \text { receptor resulted in cytidine deamination, } \\
\text { apurinic/apyrimidinic site formation and finally cccDNA degradation. }\end{array}$ & Lucifora et al., 2014 \\
\hline APOBEC3B & $\begin{array}{l}\text { Upregulation by IFN } \alpha \text { and lymphotoxin- } \beta \text { receptor resulted in cytidine deamination, } \\
\text { apurinic/apyrimidinic site formation and finally cccDNA degradation. }\end{array}$ & Lucifora et al., 2014 \\
\hline SIRT 3 & Mediates cccDNA transcription. Repression lifted by HBx. & Ren et al., 2018 \\
\hline
\end{tabular}

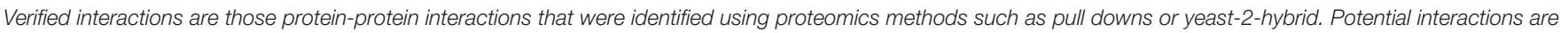
those which have been shown using methods that strongly suggest an interaction (e.g., co-localization) but were not verified using pull-down methods.

which in turn recruits the ubiquitylation machinery to send Structural Maintenance of Chromosomes protein 5/6(SMC5/6), a transcriptional repressor of cccDNA, to the proteasome for degradation. Two molecules, pevonedistat, a NEDD8-activating enzyme inhibitor, and nitazoxanide, a thiazolide anti-infective agent, have been shown to restore SMC5/6 levels and suppress viral transcription (Decorsiere et al., 2016; Sekiba et al., 2019a,b). Recently, epigenetic modifiers that specifically target viral factors involved in the regulation of cccDNA expression have been described and are currently being evaluated. Several selective inhibitors (e.g., C646) for histone acetyltransferase like CBP and P300 have been used to study the inhibitory effect on HBV transcription (Tropberger et al., 2015). The prodrug GS-5801 has also been shown to inhibit transcription from cccDNA by blocking the activity of lysine demethylase 5 (KDM5) (Gilmore et al., 2017). Although these observations show that silencing of HBV transcription is possible, the main throwback of most of these targets is the lack of desired selectivity for cccDNA and their potential to impact cellular processes.

Complete elimination of cccDNA by compromising the stability or the half-life of the molecule is often dubbed the "Holy Grail" of HBV research. Many molecules have been described that phenotypically reduce the quantity or transcription level of cccDNA. Recently, a small molecule, ccc_R08, with an unknown mode of action was shown to decrease the pool of cccDNA together with a decrease in viral transcripts and viral antigens in primary human hepatocytes $(\mathrm{PHH})$ and in an $\mathrm{HBV}$ minicircle mouse model (Wang et al., 2019). In most instances, information on the exact mechanism of such molecules is lacking implying a need to conduct target deconvolution studies to identify the respective interaction partner or process. We created a cccDNA network map, not only to visualize the currently known cccDNA interacting proteins but also to be put alongside such exercises (Figure 2). 


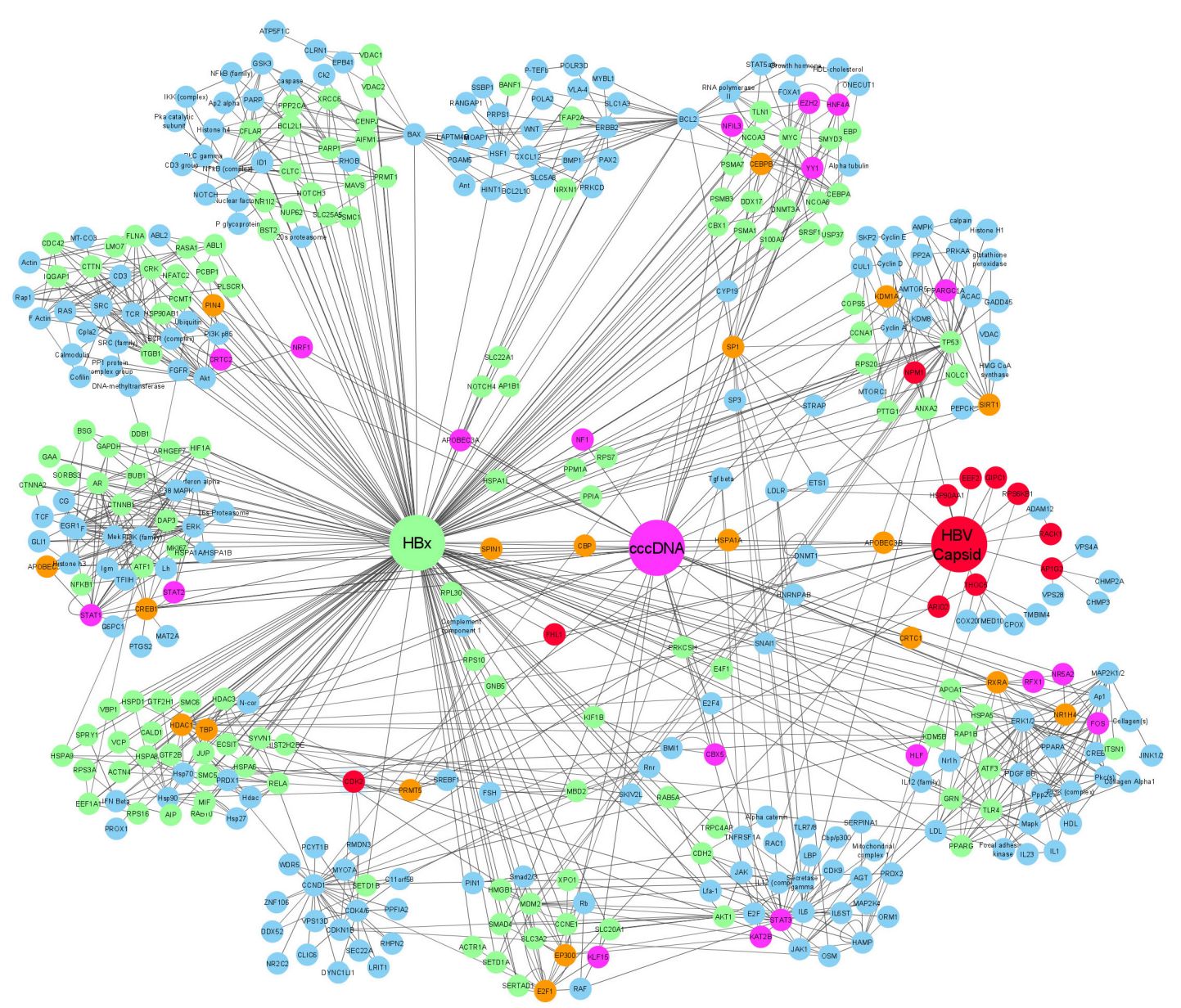

FIGURE 2 | Gene association network showing the relationship between HBx, HBc, and HBV cccDNA interacting proteins. In the network, proteins which only interact with $\mathrm{HBx}$ are indicated in green, proteins which only interact with cccDNA are shown in pink, and proteins that only interact with $\mathrm{HBc}$ are shown in red. Proteins that were shown to interact with more than two of the founding nodes (cccDNA, HBc, and HBx) are depicted in orange. proteins that were extrapolated to connect to one or more interacting proteins are shown in blue.

\section{THE HBX INTERACTOME}

The interactome of $\mathrm{HBx}$ extends beyond its interaction with the cccDNA and associated proteins. Besides nuclear interaction partners, $\mathrm{HBx}$ also interacts with various proteins in the cytoplasm, the endoplasmic reticulum (ER) and the mitochondria (Henkler et al., 2001; Huh and Siddiqui, 2002; Belloni et al., 2009; Li et al., 2017; Figure 1). This may explain why this small viral protein $(17-\mathrm{kDa})$ is not only involved in $\mathrm{HBV}$ replication, but is also shown to contribute to the development of HCC and interfere with cell cycle regulation, glucose metabolism, oxidative stress, calcium signaling, apoptosis and DNA repair (Luber et al., 1993; Waris et al., 2001; Bouchard et al., 2006; Benhenda et al., 2009; Table 2). The pivotal nature of $\mathrm{HBx}$ is demonstrated by Table 2 in which more than $250 \mathrm{HBx}$ interaction partners are summarized. However, it does need to be mentioned that some of these interactions may be very weak or very brief and their relevance may be limited.
Besides the transcriptional modulation of cccDNA, HBx has also been described to modulate gene expression of multiple proteins involved in signaling pathways such as the AKT serine/threonine kinase 1 (AKT1), Ras-Raf-mitogen-activated protein (MAP) kinase, MAPK8/pSMAD3L, (TRRI)/pSMAD3C, nuclear factor-kappa B (NF-kB) pathways and potential restriction factors such as STIM1, zinc finger E-box binding homeobox 2 (ZEB2), and proteasome activator subunit 4 (PSME4) (Benn et al., 1996; Klein and Schneider, 1997; Waris et al., 2001; Yoo et al., 2008; Zhang et al., 2012; Liu et al., 2014; Lu et al., 2015; Rawat and Bouchard, 2015; Wu et al., 2016; Yu et al., 2016; Cheng et al., 2018; Zheng et al., 2019; Minor et al., 2020; Table 2). Interestingly, HBx expression itself is also influenced by cellular proteins, for example, NRF1 has shown to bind the HBx promotor to activate it in contrast to ATF2, which showed the opposite effect (Choi et al., 1997; Tokusumi et al., 2004; Quasdorff and Protzer, 2010). 
TABLE 2 | HBx interacting proteins listed together with the cellular processes or pathways in which they are involved.

\begin{tabular}{|c|c|c|}
\hline Interaction partner & Cellular Process & References \\
\hline RPB5 & Transcriptional machinery & Cheong et al., 1995 \\
\hline TFIIB & Transcriptional machinery & Lin et al., 1997 \\
\hline TBP & Transcriptional machinery & Qadri et al., 1995 \\
\hline $\mathrm{TFIIH}$ & Transcriptional machinery & Qadri et al., 2011 \\
\hline CBP & Coactivator & Cougot et al., 2007 \\
\hline P300 & Coactivator & Cougot et al., 2007 \\
\hline PCAF & Coactivator & Chan et al., 2013 \\
\hline ATF/CREB & Transcription factor & Maguire et al., 1991 \\
\hline ATF3 & Transcription factor & Barnabas and Andrisani, 2000 \\
\hline ICERIlgamma & Transcription factor & $\begin{array}{l}\text { Barnabas et al., 1997; } \\
\text { Barnabas and Andrisani, } 2000\end{array}$ \\
\hline gadd153/Chop10 & Transcription factor & Barnabas et al., 1997 \\
\hline c/EBPA & Transcription factor & Choi et al., 1999 \\
\hline NF-IL-6 & Transcription factor & Barnabas et al., 1997 \\
\hline ETS/ERG ${ }^{\#}$ & Transcription factor & Qin et al., 2013 \\
\hline EGR/EGRF1 & Transcription factor & Yoo and Lee, 2004 \\
\hline SMAD4 & Transcription factor & Shi et al., 2016 \\
\hline Oct1 & Transcription factor & Antunovic et al., 1993 \\
\hline$R \times R$ & Transcription factor & Kong et al., 2000 \\
\hline P53 & Transcription factor. Induces destabilization of HBx. & $\begin{array}{l}\text { Belloni et al., 2009; Xian et al., } \\
\text { 2010; Iyer and Groopman, } 2011\end{array}$ \\
\hline PRMT1 & Relieves PRMT1 suppression from viral replication. & Benhenda et al., 2013 \\
\hline Spindlin1 & $\begin{array}{l}\text { Interaction with } \mathrm{HBx} \text { relieves repression by Spindlin1. Knockdown induced an increase in HBV } \\
\text { transcription and } \mathrm{H} 3 \mathrm{H} 4 \text { trimethylation on the cccDNA. }\end{array}$ & Ducroux et al., 2014 \\
\hline PP1 & HBx interferes with the inactivation of CREB/CREB1 by PP1. & Cougot et al., 2012 \\
\hline JMJD5 & Interaction with HBx facilitates HBV replication through the hydroxylase activity of JMJD5. & Kouwaki et al., 2016 \\
\hline DDB1 & Recruited resulting in SMC5/6 degradation. & Decorsiere et al., 2016 \\
\hline SMC5/6 & Recruited to the ubiquitin machinery to be degraded to enhance transcription. & Decorsiere et al., 2016 \\
\hline hepatocystin & May be an antiviral pathway, hepatocystin seems to accelerate HBx degradation. & Shin et al., 2013 \\
\hline Clathrin heavy chain & Unknown & Shin et al., 2013 \\
\hline HSPA5 & Unknown & Shin et al., 2013 \\
\hline HSPA9 & Unknown & Shin et al., 2013 \\
\hline CALD1 & Unknown & Shin et al., 2013 \\
\hline HSPA8 & Unknown & Shin et al., 2013 \\
\hline XRCC6 & Unknown & Shin et al., 2013 \\
\hline PDIA4 & Unknown & Shin et al., 2013 \\
\hline PRKCSH & Unknown & Shin et al., 2013 \\
\hline HSPA6 & Unknown & Shin et al., 2013 \\
\hline DDX17 & Unknown & Shin et al., 2013 \\
\hline HSPA1L & Unknown & Shin et al., 2013 \\
\hline HSPA1A & Unknown & Shin et al., 2013 \\
\hline SIRT1 & SIRT1 interacts with $\mathrm{HBx}$ thereby enabling $\mathrm{HBx}$-induced transcriptional activity cccDNA. & $\begin{array}{l}\text { Srisuttee et al., } 2012 \text {; } \\
\text { Deng et al., } 2017\end{array}$ \\
\hline Set1A/SETD1A \# & Recruited by HBx to cccDNA to increase transcription. & Alarcon et al., 2016 \\
\hline LSD1 ${ }^{\#}$ & Bound to viral promotors. & Alarcon et al., 2016 \\
\hline CRTC1 & Interaction associated with increased transcription. & Tang et al., 2014 \\
\hline CPAP/CENPJ & Promotes HBx-mediated cell proliferation and migration in a SUMO-dependent manner. & Yang et al., 2013 \\
\hline CREB/CREB1 & Upregulated via HBx-CREB/CREB1 interaction. & Yang et al., 2013 \\
\hline CRM1/XPO1 & Potential activation of CRM1/XPO1 and role in HBx-mediated carcinogenesis. & Forgues et al., 2001 \\
\hline $\mathrm{NF}_{\kappa} \mathrm{B}^{\#}$ & Relocalization via NES motif. & Forgues et al., 2001 \\
\hline VISA/MAVs & Disruption of VISA/MAVs and downstream interacting proteins thereby impairing IFN signaling. & Wang X. et al., 2010 \\
\hline MDA5 & Impairment of IFN signaling. & Wang X. et al., 2010 \\
\hline GRP78 & $\begin{array}{l}\text { Role in HCC via suppression of elF2 } \alpha \text { phosphorylation, inhibited expression of ATF } 4 / C H O P / B c l-2 \text {, and } \\
\text { reduced cleavage of PARP. }\end{array}$ & Li et al., 2017 \\
\hline
\end{tabular}


TABLE 2 | (Continued)

\begin{tabular}{|c|c|c|}
\hline Interaction partner & Cellular Process & References \\
\hline $\mathrm{Bcl}-2$ & Management of calcium levels to benefit viral replication. & Geng et al., 2012 \\
\hline HDAC1 & Repression insulin-like growth factor binding protein-3. HBx also induces HDAC1. & $\begin{array}{l}\text { Pollicino et al., 2006; Yoo et al., } \\
\text { 2008; Shon et al., } 2009\end{array}$ \\
\hline SP1 $1^{\#}$ & HBx induces deacetylation of SP1. & $\begin{array}{l}\text { Pollicino et al., 2006; Yoo et al., } \\
\text { 2008; Shon et al., } 2009\end{array}$ \\
\hline USP-15 & USP-15 mediated deubiquitylation protects $\mathrm{HBx}$ from proteasomal degradation. & Su et al., 2017 \\
\hline PARP1 & DNA damage and repair, carcinogenesis. & Na et al., 2016 \\
\hline Cardiolipin (lipid) & Mitochondrial membrane permeabilization. & You et al., 2019 \\
\hline Prdx1 & Peroxiredoxin interfaces with HBV-RNA to promote RNA decay, potentially HBx rescues this event. & Deng et al., 2018, 2019 \\
\hline Parvulin 14/PIN4 & $\begin{array}{l}\text { Interaction with HBx in nucleus, cytoplasm and mitochondria to enhance HBx stability, translocation to } \\
\text { the nucleus and mitochondria to increase HBV replication. }\end{array}$ & Saeed et al., 2018 \\
\hline c-myc & Oncogenesis & Lee et al., 2016 \\
\hline Orail protein & Calcium metabolism & Yao et al., 2018 \\
\hline HMGB1 & Autophagy & Fu et al., 2018 \\
\hline FXR/NR1H4 & Transactivation FXR/NR1H4, oncogenesis & Niu Y. et al., 2017 \\
\hline PP2Ac/PP2CA & Cell cycle and apoptosis & Gong et al., 2016 \\
\hline SMYD3 & Involved in AP1 activation & Hayashi et al., 2016 \\
\hline P62 & Glucose metabolism & Liu B. et al., 2015 \\
\hline TLR4 & Tumorigenesis & Wang et al., 2015 \\
\hline BST-2@ & HBV restriction factor & Lv et al., 2015 \\
\hline MBD2 & Involved in epigenetics of histones, potentially in HCC. & Liu X.Y. et al., 2015 \\
\hline TRUSS/TRPC4AP & May be linked to pathological sequelae of HBV. & Jamal et al., 2015 \\
\hline LMO7 & Cell adhesion & Zhang et al., 2015 \\
\hline ACTN4 & Cell adhesion & Zhang et al., 2015 \\
\hline CTNNA2 & Cell adhesion & Zhang et al., 2015 \\
\hline MYH2 & Cell adhesion & Zhang et al., 2015 \\
\hline FILAMIN & Cell adhesion & Zhang et al., 2015 \\
\hline ITGB1 & Cell adhesion & Zhang et al., 2015 \\
\hline TLN1 & Cell adhesion & Zhang et al., 2015 \\
\hline NRXN1 & Cell adhesion & Zhang et al., 2015 \\
\hline $\mathrm{CDH} 2$ & Cell migration & Zhang et al., 2015 \\
\hline $\mathrm{NOTCH} 4$ & Angiogenesis & Zhang et al., 2015 \\
\hline CTNNB1 & Angiogenesis & Zhang et al., 2015 \\
\hline ANXA2 & Angiogenesis & Zhang et al., 2015 \\
\hline ATP5B & Angiogenesis/cell adhesion & Zhang et al., 2015 \\
\hline PSMC4 & Protein degradation & Zhang et al., 2015 \\
\hline PSMB3 & Protein degradation & Zhang et al., 2015 \\
\hline VDAC1 & Anion transport & Zhang et al., 2015 \\
\hline VDAC2 & Anion transport & Zhang et al., 2015 \\
\hline SLC25A3 & Transport & Zhang et al., 2015 \\
\hline S100A9 & Viral reproduction & Zhang et al., 2015 \\
\hline
\end{tabular}


TABLE 2 | (Continued)

\begin{tabular}{|c|c|c|}
\hline Interaction partner & Cellular Process & References \\
\hline SLC25A10 & Metabolic process & Zhang et al., 2015 \\
\hline SLC3A2 & Immune system process & Zhang et al., 2015 \\
\hline RAP1B & Signal transduction & Zhang et al., 2015 \\
\hline RAB10 & Signal transduction & Zhang et al., 2015 \\
\hline FIS1 & Programmed cell death & Zhang et al., 2015 \\
\hline KIF1B & Programmed cell death & Zhang et al., 2015 \\
\hline DAP3 & Induction of apoptosis & Zhang et al., 2015 \\
\hline VIM & Apoptosis & Zhang et al., 2015 \\
\hline JUP & Cell migration & Zhang et al., 2015 \\
\hline RPL30 & Viral reproduction & Zhang et al., 2015 \\
\hline RPL38 & Viral reproduction & Zhang et al., 2015 \\
\hline BANF1 & Viral reproduction & Zhang et al., 2015 \\
\hline AP1B1 & Viral reproduction & Zhang et al., 2015 \\
\hline$B S G$ & Immune system process & Zhang et al., 2015 \\
\hline ACTR1A & Cell cycle & Zhang et al., 2015 \\
\hline SRSF1 & mRNA processing & Zhang et al., 2015 \\
\hline DDB1 & Wnt receptor signaling pathway & Zhang et al., 2015 \\
\hline ATP5C1 & Oxidative phosphorylation & Zhang et al., 2015 \\
\hline PCMT1 & Protein methylation & Zhang et al., 2015 \\
\hline PSMA7/XAPC7 & Proteasome & Huang et al., 1996 \\
\hline PSMC1 & Proteasome & Zhang et al., 2000 \\
\hline PSMA1 & Proteasome & Hu et al., 1999 \\
\hline PLSCR1 & Unknown & Yuan et al., 2015 \\
\hline GRN & Unknown & Yuan et al., 2015 \\
\hline SPRY1 & Unknown & Yuan et al., 2015 \\
\hline NKD2 & Unknown & Yuan et al., 2015 \\
\hline SYVN1 & Unknown & Yuan et al., 2015 \\
\hline $\mathrm{NOTCH} 3$ & Unknown & Yuan et al., 2015 \\
\hline LAMC3 & Unknown & Yuan et al., 2015 \\
\hline SERTAD1 & Unknown & Yuan et al., 2015 \\
\hline GAA & Unknown & Yuan et al., 2015 \\
\hline USP37 & Cell cycle progression & Saxena and Kumar, 2014 \\
\hline E4F1 & P53-dependent growth arrest & Dai Y. et al., 2014 \\
\hline Pregnane $\mathrm{X}$ receptor & Potentially involved in carcinogenesis & Niu et al., 2013 \\
\hline apoA-। & HBV secretion & Zhang et al., 2013 \\
\hline hBubR1/BUB1 & Genomic stability & Chae et al., 2013 \\
\hline$c-F L I P_{L}$ & Apoptosis & Kim and Seong, 2003 \\
\hline c-FLIPS & Apoptosis & Kim and Seong, 2003 \\
\hline
\end{tabular}


TABLE 2 | (Continued)

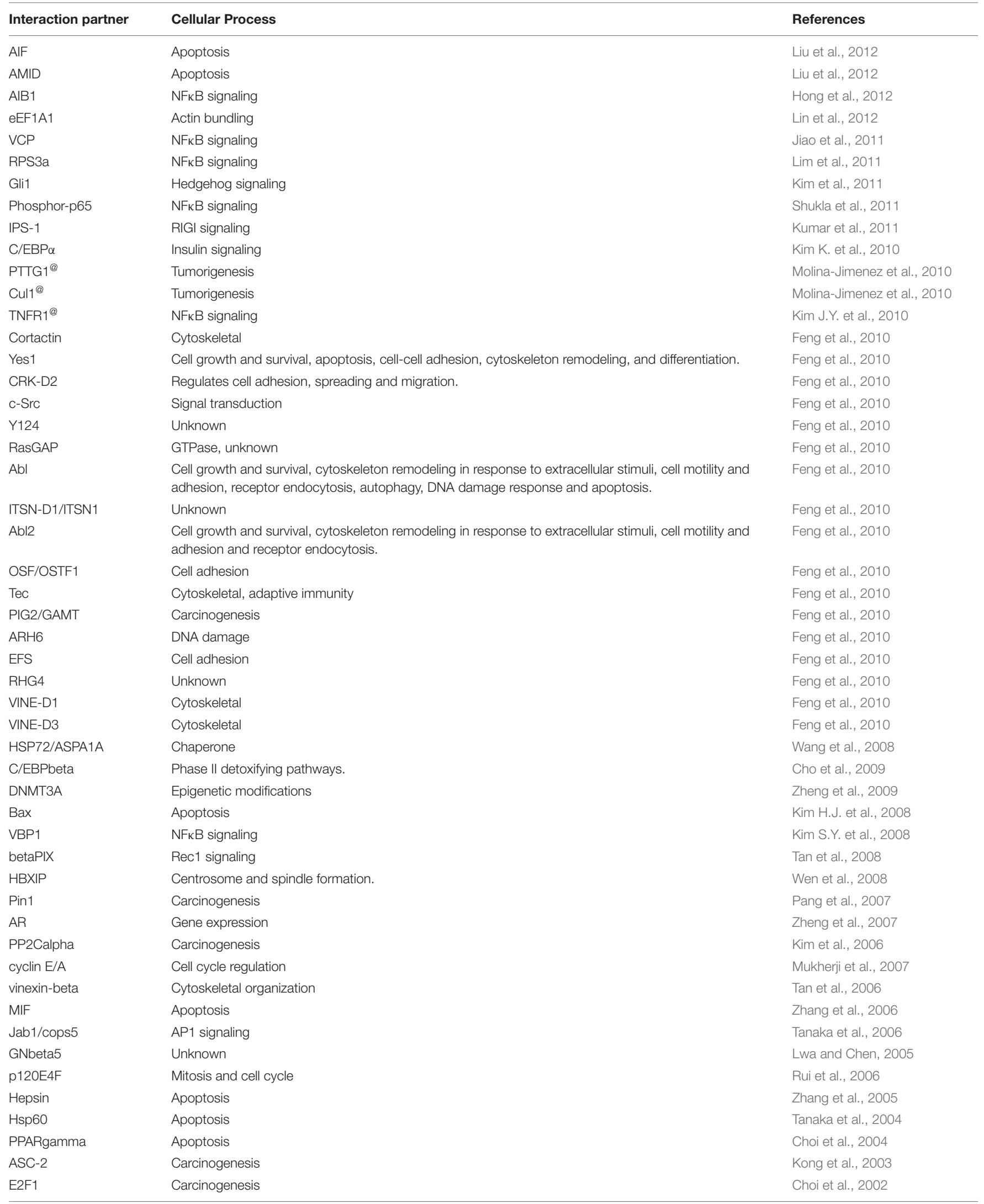


TABLE 2 | (Continued)

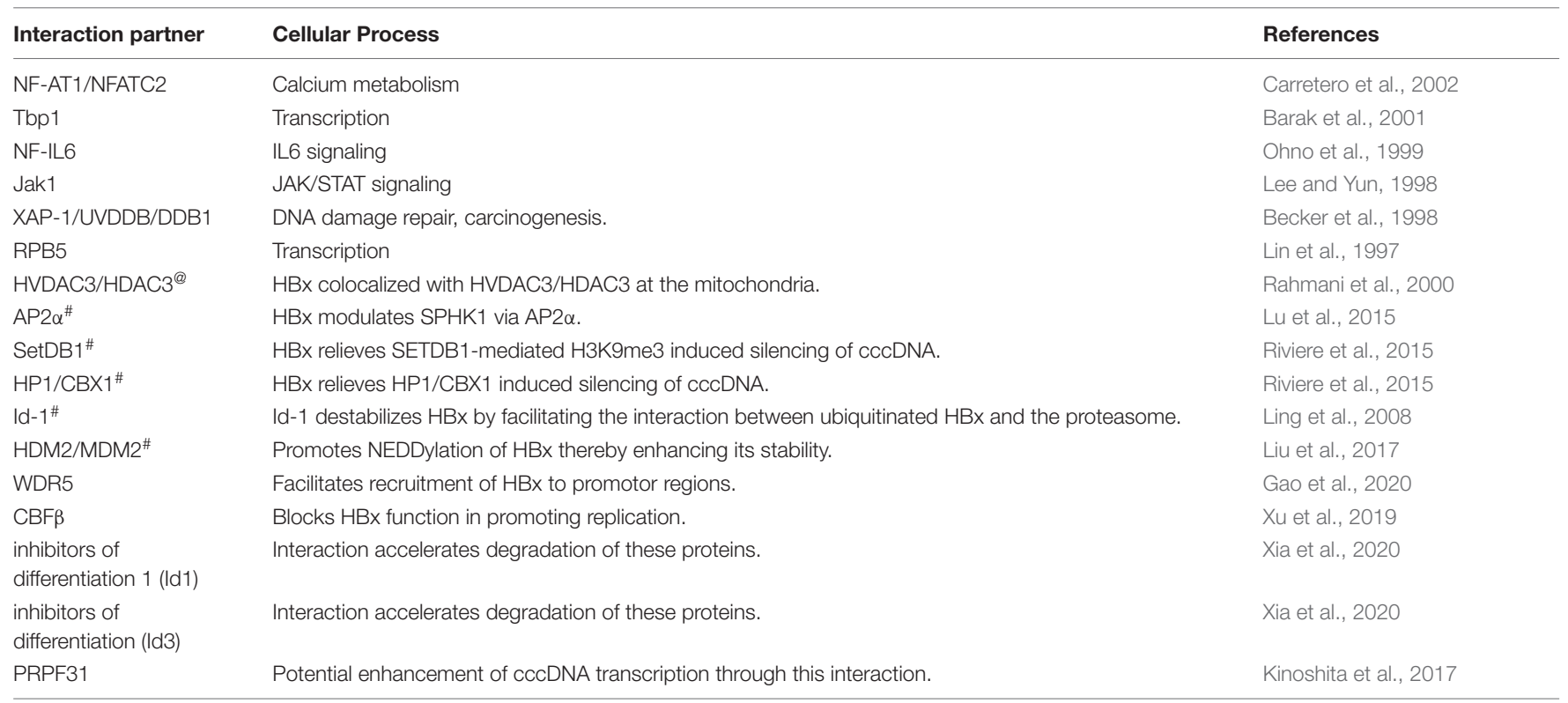

\# Unknown if this pertains a real protein-protein interaction; @ potential interaction, evidenced by co-localization.

\section{THE HBc INTERACTOME}

$\mathrm{HBc}$ is mostly known as the building block of the HBV capsid (Summers et al., 1975) but in recent years it has been shown that its function is not limited to this and also plays a role in cccDNA stability, transcription and epigenetic regulation (Newbold et al., 1995; Bock et al., 2001; Zlotnick et al., 2015; Chong et al., 2017), evasion of antiviral mechanisms (Lucifora et al., 2014), reverse transcription (Tan et al., 2015), cellular trafficking (Schmitz et al., 2010; Yang et al., 2014), genomic replication (Lott et al., 2000), and viral egress (Bardens et al., 2011). The field is also discovering more and more that $\mathrm{HBc}$ expression is extensively regulated by core promotor regulation, core mRNA modulation and post-translational modifications which highlights its importance in the life cycle (Buckwold et al., 1997; Sohn et al., 2006; Kohno et al., 2014; Qian et al., 2015; He et al., 2016; Bartusch et al., 2017; Lubyova et al., 2017; Heger-Stevic et al., 2018; Makokha et al., 2019).

Initially, the impact on the capsid made $\mathrm{HBc}$ an appealing drug-target (Berke et al., 2017). However, given that there is also an interplay with cccDNA and $\mathrm{HBx}$ these molecules may have more far-reaching consequences. As more protein interactions between $\mathrm{HBc}$ and the host are elucidated, we also compiled the interactome of the core protein and linked it to the $\mathrm{HBx}$ and cccDNA interactomes (Figure 2).

\section{A cccDNA AND HBX GENE ASSOCIATION NETWORK: EXPANDING THE POTENTIAL CCCDNA AND HBX INTERACTOME}

Tables 1-3 summarize what is currently known in the literature (manual curation) about cccDNA, $\mathrm{HBx}$ protein, and $\mathrm{HBc}$
protein-DNA and protein-protein interactions, respectively. However, to utilize this information to predict and potentially identify new protein interactions, network pathway analysis was performed (Ingenuity Pathway Analysis, IPA, Qiagen). IPA enables gene network generation from the Ingenuity Knowledge Base, a data repository of biological interactions and functional annotations.

To generate gene association networks, the $\mathrm{HBx}, \mathrm{HBc}$, and HBV cccDNA interacting proteins were individually analyzed to create three separate network schemes. The database was filtered and core analysis performed to only query the following: (1) Species = Human, (2) Molecules per networks $=35$, Networks per analysis $=10$, (3) Node Types = All, (4) Data Source $=$ All, (5) Confidence $=$ Experimentally Observed, (6) Species = Human, (7) Tissues and Cell Types = Liver, Hepatocytes, Hepatoma Cell Lines not otherwise specified, HuH7 cell line, Hep3B cell line, HepG2 cell line and "Other" Hepatoma cell lines, and (8) Mutation = All.

If proteins selected as network "seeds" were not apparently connected or networks had less than 35 gene products, IPA added proteins from the IPA Knowledge data base to maximize the connectivity of the "seed" molecules within the filter limits. We also filtered out those proteins that were only interacting with either cccDNA, $\mathrm{HBx}$, or $\mathrm{HBc}$ and had no extrapolated nodes. This kept the networks to a manageable size and reduced redundancy while deriving as much as possible biological context from the analysis. When adding molecules from the knowledge database, IPA uses a connectivity metric (edge-weighted spring layout) that prioritizes molecules that have the greatest overlap with the existing network. This means that the organization of the network in clusters is not based on proteins sharing similar pathways but is based on the number of described interactions in between those proteins. Upon completion of the IPA network generating 
TABLE 3 | HBC interacting proteins listed together with the cellular processes or pathways in which they are involved.

\begin{tabular}{|c|c|c|}
\hline Protein interaction partner & Process & References \\
\hline Filamin B & Interaction promotes replication. & Li et al., 2018 \\
\hline Nucleophosmin & Promotion of capsid assembly. & Jeong et al., 2014 \\
\hline APOBEC3B & Potential editing of DNA during reverse transcription. & Chen et al., 2018 \\
\hline SRSF10 & Acts as a restriction factor that regulates HBV RNAs levels. & Chabrolles et al., 2020 \\
\hline p70 ribosomal S6 kinase S6K1 & HBc modulates phosphorylation levels of S6K1. & Wang et al., 2021 \\
\hline PRMT5 & Methylation of the cccDNA. & Zhang Y. et al., 2017 \\
\hline Importin $\beta$ & Capsid assembly. & Chen et al., 2016 \\
\hline NIRF & Inhibition of infection. & Qian et al., 2015 \\
\hline Hsp90 & Catalyzes the formation of the capsid by binding HBc dimers. & Shim et al., 2011 \\
\hline hypermethylated in cancer $2 \mathrm{HIC2}$ & Unknown & Lin et al., 2006 \\
\hline eukaryotic translation elongation factor 2 EEF2 & Unknown & Lin et al., 2006 \\
\hline acetyl-coenzyme A synthetase 3 & Unknown & Lin et al., 2006 \\
\hline DNA polymerase gamma POLG & Unknown & Lin et al., 2006 \\
\hline putative translation initiation factor SUI & Unknown & Lin et al., 2006 \\
\hline chemokine $\mathrm{C}-\mathrm{C}$ motif receptor 5 & Unknown & Lin et al., 2006 \\
\hline mitochondrial ribosomal protein L41 MRPL41 & Unknown & Lin et al., 2006 \\
\hline kyot binding protein genes & Unknown & Lin et al., 2006 \\
\hline RanBPM & Unknown & Lin et al., 2006 \\
\hline HBeAg-binding protein 3 HBEBP3 & Unknown & Lin et al., 2006 \\
\hline programmed cell death 2 PDCD2 & Unknown & Lin et al., 2006 \\
\hline SP1 & Inhibition of anti-viral mechanism of Mitochondrial antiviral signaling protein MAVS. & Li et al., 2021 \\
\hline coactivator cAMP response element CRE & $\begin{array}{l}\text { aspecific interaction enhances the binding of the cAMP response element-binding } \\
\text { protein CREB to CRE. }\end{array}$ & Xiang et al., 2015 \\
\hline C12 protein & Unknown & Lu et al., 2005 \\
\hline SRPK2 & Mediate HBV core protein phosphorylation, unknow role in viral infection. & Daub et al., 2002 \\
\hline SRPK1 & Mediate HBV core protein phosphorylation, unknow role in viral infection. & Daub et al., 2002 \\
\hline NXF1 & Involved in cellular trafficking of $\mathrm{HBc}$ & Yang et al., 2014 \\
\hline TREX transcription/export complex & Involved in cellular trafficking of $\mathrm{HBc}$ & Yang et al., 2014 \\
\hline BAF200C & Evasion of host anti-viral mechanisms. & Li et al., 2019 \\
\hline BAF200 & Evasion of host anti-viral mechanisms. & Li et al., 2019 \\
\hline Hsp70 & Promotes capsid formation. & Seo et al., 2018 \\
\hline MxA & $\begin{array}{l}\text { Immobilizes HBc in perinuclear compartiment, possible interference with capsid } \\
\text { formation. }\end{array}$ & Li et al., 2012 \\
\hline Hdj1 & Accelerated degradation of the viral core and $\mathrm{HBx}$ proteins & Shon et al., 2009 \\
\hline hTid1 & Accelerated degradation of the viral core and $\mathrm{HBx}$ proteins & Shon et al., 2009 \\
\hline $\begin{array}{l}\text { Skeletal muscle and kidney enriched inositol } \\
\text { phosphatase SKIP }\end{array}$ & Interaction induces HBV gene suppression. & Hung et al., 2009 \\
\hline Atg12 & Modulation of authophagy. & Doring et al., 2018 \\
\hline Np95/ICBP90-like RING finger protein NIRF & Potentially involved in maturation of the virus. & Qian et al., 2012 \\
\hline PTPN3 & Supression of HBV gene expression. & Hsu et al., 2007 \\
\hline APOBEC3G & APOBEC3G is potentially incorporated in the virion through this interaction. & Zhao et al., 2010 \\
\hline PTPN3 & May be bound within the capsid, function unknown. & Genera et al., 2021 \\
\hline PML & $\begin{array}{l}\text { Link between DNA damage response and HBV replication. HBc co-localizes in } \\
\text { PML-NBs. }\end{array}$ & Chung and Tsai, 2009 \\
\hline HDAC1 & $\begin{array}{l}\text { Link between DNA damage response and HBV replication. HBc co-localizes in } \\
\text { PML-NBs. }\end{array}$ & Chung and Tsai, 2009 \\
\hline GIPC1 & Unknown. & $\begin{array}{l}\text { Razanskas and } \\
\text { Sasnauskas, } 2010\end{array}$ \\
\hline Activation-induced cytidine deaminase AID & $\mathrm{HBc}$ is the link between AID and cccDNA. & Qiao et al., 2016 \\
\hline Gamma-2 adaptin & Endosomal function and viral egress. & Rost et al., 2006 \\
\hline Nedd4 & Virus production. & Rost et al., 2006 \\
\hline ABP-276/278 & Affects viral replication via unknown mechanism. & Huang et al., 2000 \\
\hline $\mathrm{B} 23$ & Unknown & Ludgate et al., 2011 \\
\hline I2PP2A & Unknown & Ludgate et al., 2011 \\
\hline
\end{tabular}


TABLE 3 | (Continued)

\begin{tabular}{|c|c|c|}
\hline Protein interaction partner & Process & References \\
\hline APOBEC3B & $\begin{array}{l}\text { APOBEC3B A3B displays dual inhibitory effects on HBV core-associated DNA } \\
\text { synthesis. }\end{array}$ & Zhang et al., 2008 \\
\hline Receptor of activated protein kinase C 1 RACK1 & Interference in normal TNF-a-regulated apoptosis. & Jia et al., 2015 \\
\hline nucleophosmin B23 & Unknown & Lee et al., 2009 \\
\hline CDK2 & Role in disassembly of the nucleocapsid. & Liu et al., 2021 \\
\hline E2F1 & $\begin{array}{l}\mathrm{HBc} \text { reduced the DNA-binding ability of E2F1 to the binding site of the p53 promoter } \\
\text { and respectively represses expression of p53. }\end{array}$ & Kwon and Rho, 2003 \\
\hline SIRT7 & $\begin{array}{l}\text { cccDNA expression modulation, HBc functions as a bridge between cccDNA and } \\
\text { SIRT7. }\end{array}$ & Yu et al., 2021 \\
\hline HBs & Interaction prevents nuclear translocation to HBc. & Zajakina et al., 2014 \\
\hline
\end{tabular}

algorithm, two networks were produced showing both "direct" and "indirect" relationships for either $\mathrm{HBx}, \mathrm{HBc}$, or $\mathrm{HBV}$ cccDNA interacting proteins. These were then merged and exported to Cytoscape 3.7.1 using an edge weighted spring layout to create the final network illustration showing the relationship between $\mathrm{HBx}, \mathrm{HBc}$, and $\mathrm{HBV}$ cccDNA interactingproteins (Figure 2).

In the network, proteins that interact with $\mathrm{HBc}$ are depicted in red, those interacting with cccDNA in pink and those interacting with $\mathrm{HBx}$ in green. We also highlighted those proteins that were described to interact with 2 or more of our founding ( $\mathrm{HBc}, \mathrm{HBx}$, and $\mathrm{cccDNA}$ ) nodes (Figure 2). Nineteen proteins are identified (P300, TBP, PIN4, CBP, SPIN1, CEBPB, SP1, CRTC1, RXRA, NR1H4, KDM1A, HSPA1A, APOBEC3G, APOBEC 3B, CREB1, PRMT5, HDAC1, E2F1, and SIRT1) as interacting proteins of $\mathrm{HBx}, \mathrm{HBc}$, and cccDNA. These are interesting because these components may be a driving force in cccDNA transcription and maintenance. Moreover, these may be interesting proteins for further functional research as they seem to play a connecting role in the viral life cycle (Figure 2). Most of these proteins, 12 out of 19 , are regulators of transcription, for example, TBP and CRTC1 are both involved in transcription initiation; CREB1 and E2F1 are enhancers of transcription; P300, CBP, SPIN1, SP1, PRMT5, HDAC1, and SETD1B are all epigenetic modifiers that can influence the chromatin to a specific transcriptionally accessible, active state. Finally, PIN4 was described as a chromatin remodeler. Any of these proteins could be a potentially interesting target to influence transcriptional status of cccDNA. Notable is that all these transcription-related proteins have interactions with $\mathrm{HBc}$, hereby confirming a role for $\mathrm{HBc}$ beyond capsid assembly. Also interesting is the occurrence of two APOBEC proteins as partners for $\mathrm{HBx}, \mathrm{HBc}$ and cccDNA. APOBEC proteins play a role in anti-viral immunity (Stavrou and Ross, 2015) and is a means of the cell to counteract the effect of infection (Lucifora et al., 2014).

Through the IPA approach, the network was expanded from just those proteins with known interactions with $\mathrm{HBx}, \mathrm{HBc}$, or cccDNA to an additional 210 proteins (indicated in light blue) which may play a role in protein-protein or proteincccDNA interactions. While the interactions itself are verified in literature, their involvement in the HBV pathology and viral replication cycle is not confirmed yet. Hence, these proteins provide an interesting starting point for further research. Analysis of the network shows that via these interacting proteins, HBV also taps into host pathways such as cell cycle, cell signaling, DNA repair, transcription regulation and apoptosis. This is not surprising as many of these processes have been described in relation to $\mathrm{HBV}$ already. However, this is the first time description of proteins which may be involved in these processes and how they relate to the cccDNA minichromosome, $\mathrm{HBc}$ or HBx. An additional interesting observation is that many heat shock proteins (HSP) (Hsp70, Hsp90, Hsp27, HSPD1, HSPA1A, HSPA1B, HSPA8, HSPA9, HSPA1L, HSP90AB1, HSPA5, and HSPA6) were observed as interacting proteins in this network. Literature has already described that viruses rely on host HSPs for viral protein folding and induce overexpression of HSPs in the infected cells (Bolhassani and Agi, 2019). Moreover, several HSPs were associated with some viral particles (Fust et al., 2005; Bolhassani and Agi, 2019). In HBV, downregulation of Hsp70 and Hsp90 by small interfering RNA significantly inhibited HBV production. Furthermore, also a significant reduction of $\mathrm{HBV}$ secretion could be observed in HepG2.2.15 cells treated with an Hsp90 inhibitor (Liu et al., 2009; Bolhassani and Agi, 2019). Further research will be required to confirm the additional protein partners identified in this network analysis.

\section{INTERACTIONS DURING THE LATE PHASES OF HBV INFECTION}

In $\mathrm{HBV}$ infection, besides the budding of virions, there is also the shedding of an excess amount of subviral particles (Figure 1). These particles are non-infectious $22 \mathrm{~nm}$ spheres or filaments of variable length consisting solely of the HBsAg envelope protein, which may be expressed from either cccDNA or HBV DNA that is integrated into the human genome (Heermann et al., 1984; Figure 1). Budding of infectious virus and shedding of subviral particles happen via distinct pathways (Selzer and Zlotnick, 2015).

Although redundant in viral assembly, the M-protein and its interaction with calnexin has been shown to be involved in the secretion of subviral particles (Werr and Prange, 1998). In the cytoplasm, HBsAg interacts with cyclophilin A (CypA) and stimulates the extracellular secretion of CypA (Tian et al., 2010; Figure 1). Interestingly, it seems that the presence of CypA reciprocally stimulates HBsAg secretion, as 
inhibitors against CypA reduce the amount of secreted HBsAg (Phillips et al., 2015).

To construct new virions, the pgRNA is packaged together with the viral polymerase in the nucleocapsid, which is formed in the cytoplasm by assembly of $120 \mathrm{HBc}$ dimers (Lambert et al., 2007). Although not well understood, the interaction between $\mathrm{HBc}$ dimers and cellular protein nucleophosmin (B23) was shown to promote this assembly (Jeong et al., 2014; Figure 1). This nucleocapsid is surrounded by a cellular lipid layer embedded with three viral S glycoproteins, which originate from the endoplasmic reticulum (Bruss, 2007). Virion assembly depends solely on the L-protein, whereas the S-protein is required but not sufficient, and the M-protein is redundant (Bruss, 2004). To aid in building this unusual composition, Hsp70, and mammalian $\mathrm{BiP}$ were described as interaction partners of the L-protein in vitro and in vivo (Loffler-Mary et al., 1997; Lambert and Prange, 2003; Wang Y.P. et al., 2010; Figure 1). In the assembly of the mature virion, the S-protein needs to interact with the nucleocapsid (Loffler-Mary et al., 2000).

Once the mature virion is formed, it is ready to bud on the surface of the cells. The whole orchestration of this process is not clear at all, let alone accurately described in terms of interacting proteins. HBV makes use of the ESCRT, a machinery essential for the sorting of cellular cargo proteins in multivesicular bodies (Bardens et al., 2011). In this process, aryl hydrocarbon receptor interacting protein (AIP1)/ALIX and vacuolar protein sorting 4 homolog B (VPS4B) were found to colocalize with HBV particles (Kian Chua et al., 2006; Watanabe et al., 2007; Figure 1). Also, expression of dominant negative mutants of ESCRT-III complex-forming charged multivesicular body protein (CHMP) proteins (CHMP3, 4B, and $4 \mathrm{C}$ ), as well as vacuolar protein sorting 4 homolog A (VPS4A) or VPS4B mutants, and knockout of $\gamma 2$-adaptin blocked HBV assembly and egress (HartmannStuhler and Prange, 2001; Rost et al., 2006; Lambert et al., 2007; Figure 1). However, the manipulation of these proteins did not alter the secretion of subviral particles. Also involved in viral egress is Neural precursor cell Expressed, Developmentally Down-regulated 4 (NEDD) E3 ubiquitin protein ligase, which appears to control virus production by binding to the late assembly domain-like PPAY motif of HBV capsids (Rost et al., 2006; Garcia et al., 2013). It is also known that at some point, autophagy is involved in HBV production as the S-protein was shown to interact with the autophagy factor LC3 and

\section{REFERENCES}

Addison, W. R., Walters, K. A., Wong, W. W., Wilson, J. S., Madej, D., Jewell, L. D., et al. (2002). Half-life of the duck hepatitis B virus covalently closed circular DNA pool in vivo following inhibition of viral replication. J. Virol. 76, 6356-6363. doi: 10.1128/jvi.76.12.6356-6363.2002

Alarcon, V., Hernandez, S., Rubio, L., Alvarez, F., Flores, Y., Varas-Godoy, M., et al. (2016). The enzymes LSD1 and Set1A cooperate with the viral protein HBx to establish an active hepatitis B viral chromatin state. Sci. Rep. 6:25901. doi: 10.1038/srep25901

Antunovic, J., Lemieux, N., and Cromlish, J. A. (1993). The 17 kDa HBx protein encoded by hepatitis B virus interacts with the activation domains of Oct-1, and functions as a coactivator in the activation and repression of a human U6 promoter. Cell Mol. Biol. Res. 39, 463-482. manipulations to the pathway result in changes in HBV secretion (Li et al., 2011).

\section{CONCLUDING REMARKS}

The interactome we build of the cccDNA, $\mathrm{HBc}$ and $\mathrm{HBx}$ protein in this review emphasizes the vast amount of knowledge there is about the interactions between HBV proteins and in particular $\mathrm{HBx}, \mathrm{HBc}$ and the cccDNA. To our knowledge, this is the first time the information has been brought together in a comprehensive overview. Bringing this information together, it shows that there are still clear gaps in knowledge. For example, the network shows that several proteins were only described in a single publication as an interacting protein of $\mathrm{cccDNA}, \mathrm{HBc}$, or HBx. Further characterization of this kind of interactions and potentially understanding the reason behind these interactions will greatly benefit the understanding of HBV-related processes. In addition, through analysis of the known interacting proteins, we predicted 210 proteins which potentially interact with either cccDNA, $\mathrm{HBx}, \mathrm{HBc}$, or with multiple key modalities of $\mathrm{HBV}$.

Experimental verification of these proteins can lead to the discovery of novel mechanisms and expansion of known protein interaction networks.

Being able to position $\mathrm{cccDNA}, \mathrm{HBc}$ and $\mathrm{HBx}$ in the greater whole of the cellular environment is paramount to better understand how HBV hijacks the cellular environment.

\section{AUTHOR CONTRIBUTIONS}

EVD, JV, LV, and FP conceived, designed, and wrote the manuscript. BS performed the network pathway analysis, designed the gene association network, and contributed to scientific discussions about the generated network. All authors have read and edited the manuscript.

\section{ACKNOWLEDGMENTS}

JV did most of the work under the first affiliation at Johnson \& Johnson and moved then to Charles River laboratories (present address) during the writing and finalizing of the manuscript.

Barak, O., Aronheim, A., and Shaul, Y. (2001). HBV X protein targets HIV Tat-binding protein 1. Virology 283, 110-120. doi: 10.1006/viro.2001.0883

Bardens, A., Doring, T., Stieler, J., and Prange, R. (2011). Alix regulates egress of hepatitis B virus naked capsid particles in an ESCRT-independent manner. Cell Microbiol. 13, 602-619. doi: 10.1111/j.1462-5822.2010.01557.x

Barnabas, S., and Andrisani, O. M. (2000). Different regions of hepatitis B virus X protein are required for enhancement of bZip-mediated transactivation versus transrepression. J. Virol. 74, 83-90. doi: 10.1128/jvi.74.1.83-90.2000

Barnabas, S., Hai, T., and Andrisani, O. M. (1997). The hepatitis B virus X protein enhances the DNA binding potential and transcription efficacy of bZip transcription factors. J. Biol. Chem. 272, 20684-20690. doi: 10.1074/jbc.272.33. 20684

Barrasa, M. I., Guo, J. T., Saputelli, J., Mason, W. S., and Seeger, C. (2001). Does a cdc2 kinase-like recognition motif on the core protein of hepadnaviruses 
regulate assembly and disintegration of capsids? J. Virol. 75, 2024-2028. doi: 10.1128/JVI.75.4.2024-2028.2001

Bartusch, C., Doring, T., and Prange, R. (2017). Rab33B Controls Hepatitis B Virus Assembly by Regulating Core Membrane Association and Nucleocapsid Processing. Viruses 9:9060157. doi: 10.3390/v9060157

Becker, S. A., Lee, T. H., Butel, J. S., and Slagle, B. L. (1998). Hepatitis B virus X protein interferes with cellular DNA repair. J. Virol. 72, 266-272.

Belloni, L., Allweiss, L., Guerrieri, F., Pediconi, N., Volz, T., Pollicino, T., et al. (2012). IFN-alpha inhibits HBV transcription and replication in cell culture and in humanized mice by targeting the epigenetic regulation of the nuclear cccDNA minichromosome. J. Clin. Invest. 122, 529-537. doi: 10.1172/JCI58847

Belloni, L., Pollicino, T., De Nicola, F., Guerrieri, F., Raffa, G., Fanciulli, M., et al. (2009). Nuclear HBx binds the HBV minichromosome and modifies the epigenetic regulation of cccDNA function. Proc. Natl. Acad. Sci. U S A 106, 19975-19979. doi: 10.1073/pnas.0908365106

Benhenda, S., Cougot, D., Buendia, M. A., and Neuveut, C. (2009). Hepatitis B virus $\mathrm{X}$ protein molecular functions and its role in virus life cycle and pathogenesis. Adv. Cancer Res. 103, 75-109. doi: 10.1016/S0065-230X(09)03004-8

Benhenda, S., Ducroux, A., Riviere, L., Sobhian, B., Ward, M. D., Dion, S., et al. (2013). Methyltransferase PRMT1 is a binding partner of HBx and a negative regulator of hepatitis B virus transcription. J. Virol. 87, 4360-4371. doi: 10.1128/ JVI.02574-12

Benn, J., Su, F., Doria, M., and Schneider, R. J. (1996). Hepatitis B virus HBx protein induces transcription factor AP-1 by activation of extracellular signalregulated and c-Jun N-terminal mitogen-activated protein kinases. J. Virol. 70, 4978-4985.

Berke, J. M., Dehertogh, P., Vergauwen, K., Van Damme, E., Mostmans, W., Vandyck, K., et al. (2017). Capsid Assembly Modulators Have a Dual Mechanism of Action in Primary Human Hepatocytes Infected with Hepatitis B Virus. Antimicrob. Agents Chemother. 61:517. doi: 10.1128/AAC.00560-17

Bitton Alaluf, M., and Shlomai, A. (2016). New therapies for chronic hepatitis B. Liver Int. 36, 775-782. doi: 10.1111/liv.13086

Bock, C. T., Schranz, P., Schroder, C. H., and Zentgraf, H. (1994). Hepatitis B virus genome is organized into nucleosomes in the nucleus of the infected cell. Virus Genes 8, 215-229.

Bock, C. T., Schwinn, S., Locarnini, S., Fyfe, J., Manns, M. P., Trautwein, C., et al. (2001). Structural organization of the hepatitis B virus minichromosome. J. Mol. Biol. 307, 183-196. doi: 10.1006/jmbi.2000.4481

Bolhassani, A., and Agi, E. (2019). Heat shock proteins in infection. Clin. Chim. Acta 498, 90-100. doi: 10.1016/j.cca.2019.08.015

Bouchard, M. J., Wang, L., and Schneider, R. J. (2006). Activation of focal adhesion kinase by hepatitis $B$ virus $\mathrm{HBx}$ protein: multiple functions in viral replication. J. Virol. 80, 4406-4414. doi: 10.1128/JVI.80.9.4406-4414.2006

Bourne, E. J., Dienstag, J. L., Lopez, V. A., Sander, T. J., Longlet, J. M., Hall, J. G., et al. (2007). Quantitative analysis of HBV cccDNA from clinical specimens: correlation with clinical and virological response during antiviral therapy. J. Viral. Hepat. 14, 55-63. doi: 10.1111/j.1365-2893.2006.00775.x

Boyd, A., Lacombe, K., Lavocat, F., Maylin, S., Miailhes, P., Lascoux-Combe, C., et al. (2016). Decay of ccc-DNA marks persistence of intrahepatic viral DNA synthesis under tenofovir in HIV-HBV co-infected patients. J. Hepatol. 65, 683-691. doi: 10.1016/j.jhep.2016.05.014

Bruss, V. (2004). Envelopment of the hepatitis B virus nucleocapsid. Virus Res. 106, 199-209. doi: 10.1016/j.virusres.2004.08.016

Bruss, V. (2007). Hepatitis B virus morphogenesis. World J. Gastroenterol. 13, 65-73.

Buckwold, V. E., Chen, M., and Ou, J. H. (1997). Interaction of transcription factors RFX1 and MIBP1 with the gamma motif of the negative regulatory element of the hepatitis B virus core promoter. Virology 227, 515-518. doi: 10.1006/viro.1996.8360

Cai, D., Mills, C., Yu, W., Yan, R., Aldrich, C. E., Saputelli, J. R., et al. (2012). Identification of disubstituted sulfonamide compounds as specific inhibitors of hepatitis B virus covalently closed circular DNA formation. Antimicrob. Agents Chemother. 56, 4277-4288. doi: 10.1128/AAC.00473-12

Cai, Y. N., Zhou, Q., Kong, Y. Y., Li, M., Viollet, B., Xie, Y. H., et al. (2003). LRH-1/hB1F and HNF1 synergistically up-regulate hepatitis B virus gene transcription and DNA replication. Cell Res. 13, 451-458. doi: 10.1038/sj.cr. 7290187
Carretero, M., Gomez-Gonzalo, M., Lara-Pezzi, E., Benedicto, I., Aramburu, J., Martinez-Martinez, S., et al. (2002). The hepatitis B virus X protein binds to and activates the $\mathrm{NH}(2)$-terminal trans-activation domain of nuclear factor of activated T cells-1. Virology 299, 288-300.

Chabrolles, H., Auclair, H., Vegna, S., Lahlali, T., Pons, C., Michelet, M., et al. (2020). Hepatitis B virus Core protein nuclear interactome identifies SRSF10 as a host RNA-binding protein restricting HBV RNA production. PLoS Pathog. 16:e1008593. doi: 10.1371/journal.ppat.1008593

Chae, S., Ji, J. H., Kwon, S. H., Lee, H. S., Lim, J. M., Kang, D., et al. (2013). HBxAPalpha/Rsf-1-mediated HBx-hBubR1 interactions regulate the mitotic spindle checkpoint and chromosome instability. Carcinogenesis 34, 1680-1688. doi: 10.1093/carcin/bgt105

Chan, C., Wang, Y., Chow, P. K., Chung, A. Y., Ooi, L. L., and Lee, C. G. (2013). Altered binding site selection of $\mathrm{p} 53$ transcription cassettes by hepatitis B virus X protein. Mol. Cell Biol. 33, 485-497. doi: 10.1128/MCB.01189-12

Chen, C., Wang, J. C., Pierson, E. E., Keifer, D. Z., Delaleau, M., Gallucci, L., et al. (2016). Importin beta Can Bind Hepatitis B Virus Core Protein and Empty Core-Like Particles and Induce Structural Changes. PLoS Pathog. 12:e1005802. doi: 10.1371/journal.ppat.1005802

Chen, W. N., Liu, L. L., Jiao, B. Y., Lin, W. S., Lin, X. J., and Lin, X. (2015). Hepatitis B virus X protein increases the IL-1beta-induced NF-kappaB activation via interaction with evolutionarily conserved signaling intermediate in Toll pathways (ECSIT). Virus Res. 195, 236-245. doi: 10.1016/j.virusres.2014. 10.025

Chen, Y., Hu, J., Cai, X., Huang, Y., Zhou, X., Tu, Z., et al. (2018). APOBEC3B edits HBV DNA and inhibits HBV replication during reverse transcription. Antiviral. Res. 149, 16-25. doi: 10.1016/j.antiviral.2017.11.006

Cheng, S. T., Ren, J. H., Cai, X. F., Jiang, H., and Chen, J. (2018). HBx-elevated SIRT2 promotes HBV replication and hepatocarcinogenesis. Biochem. Biophys. Res. Commun. 496, 904-910. doi: 10.1016/j.bbrc.2018.01.127

Cheong, J. H., Yi, M., Lin, Y., and Murakami, S. (1995). Human RPB5, a subunit shared by eukaryotic nuclear RNA polymerases, binds human hepatitis B virus $\mathrm{X}$ protein and may play a role in $\mathrm{X}$ transactivation. EMBO J. 14, 143-150.

Cho, I. J., Ki, S. H., Brooks, C. III, and Kim, S. G. (2009). Role of hepatitis B virus $\mathrm{X}$ repression of $\mathrm{C} / \mathrm{EBPbeta}$ activity in the down-regulation of glutathione S-transferase A2 gene: implications in other phase II detoxifying enzyme expression. Xenobiotica 39, 182-192. doi: 10.1080/00498250802549808

Choi, B. H., Park, G. T., and Rho, H. M. (1999). Interaction of hepatitis B viral X protein and CCAAT/ enhancer-binding protein alpha synergistically activates the hepatitis B viral enhancer II/pregenomic promoter. J. Biol. Chem. 274, 2858-2865. doi: 10.1074/jbc.274.5.2858

Choi, C. Y., Choi, B. H., Park, G. T., and Rho, H. M. (1997). Activating transcription factor 2 (ATF2) down-regulates hepatitis B virus X promoter activity by the competition for the activating protein 1 binding site and the formation of the ATF2-Jun heterodimer. J. Biol. Chem. 272, 16934-16939.

Choi, M., Lee, H., and Rho, H. M. (2002). E2F1 activates the human p53 promoter and overcomes the repressive effect of hepatitis B viral $\mathrm{X}$ protein $(\mathrm{Hbx})$ on the p53 promoter. IUBMB Life 53, 309-317. doi: 10.1080/15216540213466

Choi, Y. H., Kim, H. I., Seong, J. K., Yu, D. Y., Cho, H., Lee, M. O., et al. (2004). Hepatitis B virus X protein modulates peroxisome proliferator-activated receptor gamma through protein-protein interaction. FEBS Lett. 557, 73-80.

Chong, C. K., Cheng, C. Y. S., Tsoi, S. Y. J., Huang, F. Y., Liu, F., Seto, W. K., et al. (2017). Role of hepatitis B core protein in HBV transcription and recruitment of histone acetyltransferases to cccDNA minichromosome. Antiviral. Res. 144, 1-7. doi: 10.1016/j.antiviral.2017.05.003

Chung, Y. L., and Tsai, T. Y. (2009). Promyelocytic leukemia nuclear bodies link the DNA damage repair pathway with hepatitis B virus replication: implications for hepatitis B virus exacerbation during chemotherapy and radiotherapy. Mol. Cancer Res. 7, 1672-1685. doi: 10.1158/1541-7786.MCR-09-0112

Cougot, D., Allemand, E., Riviere, L., Benhenda, S., Duroure, K., Levillayer, F., et al. (2012). Inhibition of PP1 phosphatase activity by HBx: a mechanism for the activation of hepatitis B virus transcription. Sci. Signal 5:ra1. doi: 10.1126/ scisignal.2001906

Cougot, D., Wu, Y., Cairo, S., Caramel, J., Renard, C. A., Levy, L., et al. (2007). The hepatitis B virus X protein functionally interacts with CREB-binding protein/p300 in the regulation of CREB-mediated transcription. J. Biol. Chem. 282, 4277-4287. doi: 10.1074/jbc.M606774200 
Cui, X., Mcallister, R., Boregowda, R., Sohn, J. A., Cortes Ledesma, F., Caldecott, K. W., et al. (2015). Does Tyrosyl DNA Phosphodiesterase-2 Play a Role in Hepatitis B Virus Genome Repair? PLoS One 10:e0128401. doi: 10.1371/journal. pone. 0128401

Dai, X., Zhang, W., Zhang, H., Sun, S., Yu, H., Guo, Y., et al. (2014). Modulation of HBV replication by microRNA-15b through targeting hepatocyte nuclear factor 1alpha. Nucleic Acids Res. 42, 6578-6590. doi: 10.1093/nar/gku260

Dai, Y., Cros, M. P., Pontoizeau, C., Elena-Hermann, B., Bonn, G. K., and Hainaut, P. (2014). Downregulation of transcription factor E4F1 in hepatocarcinoma cells: HBV-dependent effects on autophagy, proliferation and metabolism. Carcinogenesis 35, 635-650. doi: 10.1093/carcin/bgt353

Dandri, M., Burda, M. R., Will, H., and Petersen, J. (2000). Increased hepatocyte turnover and inhibition of woodchuck hepatitis B virus replication by adefovir in vitro do not lead to reduction of the closed circular DNA. Hepatology 32, 139-146. doi: 10.1053/jhep.2000.8701

Daub, H., Blencke, S., Habenberger, P., Kurtenbach, A., Dennenmoser, J., Wissing, J., et al. (2002). Identification of SRPK1 and SRPK2 as the major cellular protein kinases phosphorylating hepatitis B virus core protein. J. Virol. 76, 8124-8137.

Davis, L. G., Weber, D. J., and Lemon, S. M. (1989). Horizontal transmission of hepatitis B virus. Lancet 1, 889-893.

Decorsiere, A., Mueller, H., Van Breugel, P. C., Abdul, F., Gerossier, L., Beran, R. K., et al. (2016). Hepatitis B virus X protein identifies the Smc5/6 complex as a host restriction factor. Nature 531, 386-389. doi: 10.1038/nature17170

Deng, J. J., Kong, K. E., Gao, W. W., Tang, H. V., Chaudhary, V., Cheng, Y., et al. (2017). Interplay between SIRT1 and hepatitis B virus X protein in the activation of viral transcription. Biochim. Biophys. Acta 1860, 491-501. doi: 10.1016/j.bbagrm.2017.02.007

Deng, L., Gan, X., Ito, M., Chen, M., Aly, H. H., Matsui, C., et al. (2018). Peroxiredoxin 1, a novel $\mathrm{HBx}$-interacting protein, interacts with Exosc5 and negatively regulates $\mathrm{HBV}$ propagation through degradation of HBV RNA. J. Virol. 2018:2218. doi: 10.1128/JVI.02203-18

Deng, L., Gan, X., Ito, M., Chen, M., Aly, H. H., Matsui, C., et al. (2019). Peroxiredoxin 1, a Novel HBx-Interacting Protein, Interacts with Exosome Component 5 and Negatively Regulates Hepatitis B Virus (HBV) Propagation through Degradation of HBV RNA. J. Virol. 93:2218.

Doring, T., Zeyen, L., Bartusch, C., and Prange, R. (2018). Hepatitis B Virus Subverts the Autophagy Elongation Complex Atg5-12/16L1 and Does Not Require Atg8/LC3 Lipidation for Viral Maturation. J. Virol. 92:1517. doi: 10. 1128/JVI.01513-17

Ducroux, A., Benhenda, S., Riviere, L., Semmes, O. J., Benkirane, M., and Neuveut, C. (2014). The Tudor domain protein Spindlin1 is involved in intrinsic antiviral defense against incoming hepatitis B Virus and herpes simplex virus type 1. PLoS Pathog. 10:e1004343. doi: 10.1371/journal.ppat.1004343

Fanning, G. C., Zoulim, F., Hou, J., and Bertoletti, A. (2019). Therapeutic strategies for hepatitis B virus infection: towards a cure. Nat. Rev. Drug Discov. 18, 827-844. doi: 10.1038/s41573-019-0037-0

Fay, N., and Pante, N. (2015). Nuclear entry of DNA viruses. Front. Microbiol. 6:467. doi: 10.3389/fmicb.2015.00467

Feng, H., Tan, T. L., Niu, D., and Chen, W. N. (2010). HBV X protein interacts with cytoskeletal signaling proteins through SH3 binding. Front. Biosci. 2, 143-150.

Forgues, M., Marrogi, A. J., Spillare, E. A., Wu, C. G., Yang, Q., Yoshida, M., et al. (2001). Interaction of the hepatitis B virus X protein with the Crm1dependent nuclear export pathway. J. Biol. Chem. 276, 22797-22803. doi: 10. 1074/jbc.M101259200

Fu, S., Wang, J., Hu, X., Zhou, R. R., Fu, Y., Tang, D., et al. (2018). Crosstalk between hepatitis $\mathrm{B}$ virus $\mathrm{X}$ and high-mobility group box 1 facilitates autophagy in hepatocytes. Mol. Oncol. 12, 322-338. doi: 10.1002/1878-0261. 12165

Fust, G., Beck, Z., Banhegyi, D., Kocsis, J., Biro, A., and Prohaszka, Z. (2005). Antibodies against heat shock proteins and cholesterol in HIV infection. Mol. Immunol. 42, 79-85. doi: 10.1016/j.molimm.2004.07.003

Gallucci, L., and Kann, M. (2017). Nuclear Import of Hepatitis B Virus Capsids and Genome. Viruses 9:9010021. doi: 10.3390/v9010021

Gao, W., Jia, Z., Tian, Y., Yang, P., Sun, H., Wang, C., et al. (2020). HBx Protein Contributes to Liver Carcinogenesis by H3K4me3 Modification Through Stabilizing WD Repeat Domain 5 Protein. Hepatology 71, 1678-1695. doi: 10. 1002/hep.30947
Garcia, M. L., Reynolds, T. D., Mothes, W., and Robek, M. D. (2013). Functional characterization of the putative hepatitis B virus core protein late domain using retrovirus chimeras. PLoS One 8:e72845. doi: 10.1371/journal.pone.0072845

Genera, M., Quioc-Salomon, B., Nourisson, A., Colcombet-Cazenave, B., Haouz, A., Mechaly, A., et al. (2021). Molecular basis of the interaction of the human tyrosine phosphatase PTPN3 with the hepatitis B virus core protein. Sci. Rep. 11:944. doi: 10.1038/s41598-020-79580-9

Geng, X., Huang, C., Qin, Y., Mccombs, J. E., Yuan, Q., Harry, B. L., et al. (2012). Hepatitis $\mathrm{B}$ virus $\mathrm{X}$ protein targets $\mathrm{Bcl}-2$ proteins to increase intracellular calcium, required for virus replication and cell death induction. Proc. Natl. Acad. Sci. US A 109, 18471-18476. doi: 10.1073/pnas.1204668109

Gilmore, D. T., Dick, R., Appleby, T., Birkus, G., Willkom, M., Delaney, W. E., et al. (2017). Antiviral activity of GS-5801, a liver-targeted prodrug of a lysine demethylase 5 inhibitor, in a hepatitis B virus primary human hepatocyte infection model. J. Hepatol. 66, S690-S691. doi: 10.1016/S0168-8278(17) 31855-X

Gong, S. J., Feng, X. J., Song, W. H., Chen, J. M., Wang, S. M., Xing, D. J., et al. (2016). Upregulation of PP2Ac predicts poor prognosis and contributes to aggressiveness in hepatocellular carcinoma. Cancer Biol. Ther. 17, 151-162. doi: 10.1080/15384047.2015.1121345

Gripon, P., Cannie, I., and Urban, S. (2005). Efficient inhibition of hepatitis B virus infection by acylated peptides derived from the large viral surface protein. J. Virol. 79, 1613-1622. doi: 10.1128/JVI.79.3.1613-1622.2005

Guo, H., Xu, C., Zhou, T., Block, T. M., and Guo, J. T. (2012). Characterization of the host factors required for hepadnavirus covalently closed circular (ccc) DNA formation. PLoS One 7:e43270. doi: 10.1371/journal.pone.0043270

Guo, L., Wang, X., Ren, L., Zeng, M., Wang, S., Weng, Y., et al. (2014). HBx affects CUL4-DDB1 function in both positive and negative manners. Biochem. Biophys. Res. Commun. 450, 1492-1497. doi: 10.1016/j.bbrc.2014.07.019:10.1016/j.bbrc. 2014.07.019

Guo, Y. H., Li, Y. N., Zhao, J. R., Zhang, J., and Yan, Z. (2011). HBc binds to the CpG islands of HBV cccDNA and promotes an epigenetic permissive state. Epigenetics 6, 720-726.

Hao, R., He, J., Liu, X., Gao, G., Liu, D., Cui, L., et al. (2015). Inhibition of hepatitis $\mathrm{B}$ virus gene expression and replication by hepatocyte nuclear factor 6. J. Virol. 89, 4345-4355. doi: 10.1128/JVI.03094-14

Hao, Z., Zheng, L., Kluwe, L., and Huang, W. (2012). Ferritin light chain and squamous cell carcinoma antigen 1 are coreceptors for cellular attachment and entry of hepatitis B virus. Int. J. Nanomedicine 7, 827-834. doi: 10.2147/IJN. S27803:10.2147/IJN.S27803

Hartmann-Stuhler, C., and Prange, R. (2001). Hepatitis B virus large envelope protein interacts with gamma2-adaptin, a clathrin adaptor-related protein. J. Virol. 75, 5343-5351. doi: 10.1128/JVI.75.11.5343-5351.2001

Hayashi, M., Deng, L., Chen, M., Gan, X., Shinozaki, K., Shoji, I., et al. (2016). Interaction of the hepatitis $\mathrm{B}$ virus $\mathrm{X}$ protein with the lysine methyltransferase SET and MYND domain-containing 3 induces activator protein 1 activation. Microbiol. Immunol. 60, 17-25. doi: 10.1111/1348-0421.12345

He, Q., Li, W., Ren, J., Huang, Y., Huang, Y., Hu, Q., et al. (2016). ZEB2 inhibits HBV transcription and replication by targeting its core promoter. Oncotarget 7 , 16003-16011. doi: 10.18632/oncotarget.7435

Heermann, K. H., Goldmann, U., Schwartz, W., Seyffarth, T., Baumgarten, H., and Gerlich, W. H. (1984). Large surface proteins of hepatitis B virus containing the pre-s sequence. J. Virol. 52, 396-402.

Heger-Stevic, J., Zimmermann, P., Lecoq, L., Bottcher, B., and Nassal, M. (2018). Hepatitis B virus core protein phosphorylation: Identification of the SRPK1 target sites and impact of their occupancy on RNA binding and capsid structure. PLoS Pathog. 14:e1007488. doi: 10.1371/journal.ppat.1007488

Henkler, F., Hoare, J., Waseem, N., Goldin, R. D., Mcgarvey, M. J., Koshy, R., et al. (2001). Intracellular localization of the hepatitis B virus HBx protein. J. Gen. Virol. 82, 871-882. doi: 10.1099/0022-1317-82-4-871

Hodgson, A. J., Hyser, J. M., Keasler, V. V., Cang, Y., and Slagle, B. L. (2012). Hepatitis $\mathrm{B}$ virus regulatory $\mathrm{HBx}$ protein binding to $\mathrm{DDB} 1$ is required but is not sufficient for maximal HBV replication. Virology 426, 73-82. doi: 10.1016/j. virol.2012.01.021

Hong, A., Han, D. D., Wright, C. J., Burch, T., Piper, J., Osiowy, C., et al. (2012). The interaction between hepatitis $\mathrm{B}$ virus $\mathrm{X}$ protein and AIB1 oncogene is required for the activation of NFkappaB signal transduction. Biochem. Biophys. 
Res. Commun. 423, 6-12. doi: 10.1016/j.bbrc.2012.05.021:10.1016/j.bbrc.2012. 05.021

Hsu, E. C., Lin, Y. C., Hung, C. S., Huang, C. J., Lee, M. Y., Yang, S. C., et al. (2007). Suppression of hepatitis B viral gene expression by protein-tyrosine phosphatase PTPN3. J. Biomed. Sci. 14, 731-744. doi: 10.1007/s11373-0079187-x

Hu, Z., Zhang, Z., Doo, E., Coux, O., Goldberg, A. L., and Liang, T. J. (1999). Hepatitis B virus $X$ protein is both a substrate and a potential inhibitor of the proteasome complex. J. Virol. 73, 7231-7240.

Huang, C. J., Chen, Y. H., and Ting, L. P. (2000). Hepatitis B virus core protein interacts with the C-terminal region of actin-binding protein. J. Biomed. Sci. 7, 160-168. doi: 10.1007/BF02256623

Huang, H. C., Chen, C. C., Chang, W. C., Tao, M. H., and Huang, C. (2012). Entry of hepatitis $\mathrm{B}$ virus into immortalized human primary hepatocytes by clathrindependent endocytosis. J. Virol. 86, 9443-9453. doi: 10.1128/JVI.00873-12

Huang, J., Kwong, J., Sun, E. C., and Liang, T. J. (1996). Proteasome complex as a potential cellular target of hepatitis B virus X protein. J. Virol. 70, 5582-5591.

Huang, Q., Zhou, B., Cai, D., Zong, Y., Wu, Y., Liu, S., et al. (2021). Rapid Turnover of Hepatitis B Virus Covalently Closed Circular DNA Indicated by Monitoring Emergence and Reversion of Signature-Mutation in Treated Chronic Hepatitis B Patients. Hepatology 73, 41-52. doi: 10.1002/hep.31240

Huh, K. W., and Siddiqui, A. (2002). Characterization of the mitochondrial association of hepatitis B virus X protein, HBx. Mitochondrion 1, 349-359.

Hung, C. S., Lin, Y. L., Wu, C. I., Huang, C. J., and Ting, L. P. (2009). Suppression of hepatitis B viral gene expression by phosphoinositide 5-phosphatase SKIP. Cell Microbiol. 11, 37-50. doi: 10.1111/j.1462-5822.2008.01235.x

Ishida, H., Ueda, K., Ohkawa, K., Kanazawa, Y., Hosui, A., Nakanishi, F., et al. (2000). Identification of multiple transcription factors, HLF, FTF, and E4BP4, controlling hepatitis B virus enhancer II. J. Virol. 74, 1241-1251.

Iwamoto, M., Saso, W., Sugiyama, R., Ishii, K., Ohki, M., Nagamori, S., et al. (2019). Epidermal growth factor receptor is a host-entry cofactor triggering hepatitis B virus internalization. Proc. Natl. Acad. Sci. U S A 116, 8487-8492. doi: $10.1073 /$ pnas. 1811064116

Iyer, S., and Groopman, J. D. (2011). Interaction of mutant hepatitis B X protein with p53 tumor suppressor protein affects both transcription and cell survival. Mol. Carcinog. 50, 972-980. doi: 10.1002/mc.20767:10.1002/mc.20767

Jamal, A., Swarnalatha, M., Sultana, S., Joshi, P., Panda, S. K., and Kumar, V. (2015). The G1 phase E3 ubiquitin ligase TRUSS that gets deregulated in human cancers is a novel substrate of the S-phase E3 ubiquitin ligase Skp2. Cell Cycle 14, 2688-2700. doi: 10.1080/15384101.2015.1056946

Jeong, H., Cho, M. H., Park, S. G., and Jung, G. (2014). Interaction between nucleophosmin and HBV core protein increases HBV capsid assembly. FEBS Lett. 588, 851-858. doi: 10.1016/j.febslet.2014.01.020

Jia, B., Guo, M., Li, G., Yu, D., Zhang, X., Lan, K., et al. (2015). Hepatitis B virus core protein sensitizes hepatocytes to tumor necrosis factor-induced apoptosis by suppression of the phosphorylation of mitogen-activated protein kinase kinase 7. J. Virol. 89, 2041-2051. doi: 10.1128/JVI.03106-14

Jiao, B. Y., Lin, W. S., She, F. F., Chen, W. N., and Lin, X. (2011). Hepatitis B virus X protein enhances activation of nuclear factor kappaB through interaction with valosin-containing protein. Arch. Virol. 156, 2015-2021. doi: 10.1007/s00705011-1099-4

Kalra, N., and Kumar, V. (2006). The X protein of hepatitis B virus binds to the F box protein Skp2 and inhibits the ubiquitination and proteasomal degradation of c-Myc. FEBS Lett. 580, 431-436. doi: 10.1016/j.febslet.2005.12.034

Kann, M., Sodeik, B., Vlachou, A., Gerlich, W. H., and Helenius, A. (1999). Phosphorylation-dependent binding of hepatitis B virus core particles to the nuclear pore complex. J. Cell Biol. 145, 45-55.

Kau, J. H., and Ting, L. P. (1998). Phosphorylation of the core protein of hepatitis B virus by a 46-kilodalton serine kinase. J. Virol. 72, 3796-3803.

Khattar, E., Mukherji, A., and Kumar, V. (2012). Akt augments the oncogenic potential of the HBx protein of hepatitis $\mathrm{B}$ virus by phosphorylation. FEBS J. 279, 1220-1230. doi: 10.1111/j.1742-4658.2012.08514.x

Kian Chua, P., Lin, M. H., and Shih, C. (2006). Potent inhibition of human Hepatitis B virus replication by a host factor Vps4. Virology 354, 1-6. doi: 10.1016/j.virol.2006.07.018

Kim, B. K., Lim, S. O., and Park, Y. G. (2008). Requirement of the cyclic adenosisne monophosphate response element-binding protein for hepatitis $\mathrm{B}$ virus replication. Hepatology 48, 361-373. doi: 10.1002/hep.22359
Kim, H. J., Kim, S. Y., Kim, J., Lee, H., Choi, M., Kim, J. K., et al. (2008). Hepatitis $\mathrm{B}$ virus $\mathrm{X}$ protein induces apoptosis by enhancing translocation of Bax to mitochondria. IUBMB Life 60, 473-480. doi: 10.1002/iub.68

Kim, H. Y., Cho, H. K., Hong, S. P., and Cheong, J. (2011). Hepatitis B virus X protein stimulates the Hedgehog-Gli activation through protein stabilization and nuclear localization of Gli1 in liver cancer cells. Cancer Lett. 309, 176-184. doi: 10.1016/j.canlet.2011.05.033

Kim, J. S., Rho, B., Lee, T. H., Lee, J. M., Kim, S. J., and Park, J. H. (2006). The interaction of hepatitis B virus $\mathrm{X}$ protein and protein phosphatase type 2 Calpha and its effect on IL-6. Biochem. Biophys. Res. Commun. 351, 253-258. doi: 10.1016/j.bbrc.2006.10.028

Kim, J. Y., Song, E. H., Lee, H. J., Oh, Y. K., Choi, K. H., Yu, D. Y., et al. (2010). HBx-induced hepatic steatosis and apoptosis are regulated by TNFR1- and NF-kappaB-dependent pathways. J. Mol. Biol. 397, 917-931. doi: 10.1016/j.jmb. 2010.02.016

Kim, K. H., and Seong, B. L. (2003). Pro-apoptotic function of HBV X protein is mediated by interaction with c-FLIP and enhancement of death-inducing signal. EMBO J. 22, 2104-2116. doi: 10.1093/emboj/cdg210

Kim, K., Kim, K. H., and Cheong, J. (2010). Hepatitis B virus X protein impairs hepatic insulin signaling through degradation of IRS1 and induction of SOCS3. PLoS One 5:e8649. doi: 10.1371/journal.pone.0008649

Kim, S. Y., Kim, J. C., Kim, J. K., Kim, H. J., Lee, H. M., Choi, M. S., et al. (2008). Hepatitis B virus X protein enhances NFkappaB activity through cooperating with VBP1. BMB Rep. 41, 158-163.

Kim, W. R. (2018). Emerging Therapies Toward a Functional Cure for Hepatitis B Virus Infection. Gastroenterol. Hepatol. 14, 439-442.

Kinoshita, W., Ogura, N., Watashi, K., and Wakita, T. (2017). Host factor PRPF31 is involved in cccDNA production in HBV-replicating cells. Biochem. Biophys. Res. Commun. 482, 638-644. doi: 10.1016/j.bbrc.2016.11.085

Kitamura, K., Que, L., Shimadu, M., Koura, M., Ishihara, Y., Wakae, K., et al. (2018). Flap endonuclease 1 is involved in cccDNA formation in the hepatitis B virus. PLoS Pathog. 14:e1007124. doi: 10.1371/journal.ppat.1007124

Klein, N. P., and Schneider, R. J. (1997). Activation of Src family kinases by hepatitis B virus HBx protein and coupled signaling to Ras. Mol. Cell Biol. 17, 6427-6436.

Ko, C., Lee, S., Windisch, M. P., and Ryu, W. S. (2014). DDX3 DEAD-box RNA helicase is a host factor that restricts hepatitis $\mathrm{B}$ virus replication at the transcriptional level. J. Virol. 88, 13689-13698. doi: 10.1128/JVI.02035-14

Kock, J., Rosler, C., Zhang, J. J., Blum, H. E., Nassal, M., and Thoma, C. (2010). Generation of covalently closed circular DNA of hepatitis B viruses via intracellular recycling is regulated in a virus specific manner. PLoS Pathog. 6:e1001082. doi: 10.1371/journal.ppat.1001082

Kohno, T., Tsuge, M., Murakami, E., Hiraga, N., Abe, H., Miki, D., et al. (2014). Human microRNA hsa-miR-1231 suppresses hepatitis B virus replication by targeting core mRNA. J. Viral. Hepat. 21, e89-e97. doi: 10.1111/jvh.12240

Kong, H. J., Hong, S. H., Lee, M. Y., Kim, H. D., Lee, J. W., and Cheong, J. (2000). Direct binding of hepatitis $\mathrm{B}$ virus $\mathrm{X}$ protein and retinoid $\mathrm{X}$ receptor contributes to phosphoenolpyruvate carboxykinase gene transactivation. FEBS Lett. 483, 114-118. doi: 10.1016/s0014-5793(00)02091-3

Kong, H. J., Park, M. J., Hong, S., Yu, H. J., Lee, Y. C., Choi, Y. H., et al. (2003). Hepatitis B virus X protein regulates transactivation activity and protein stability of the cancer-amplified transcription coactivator ASC-2. Hepatology 38, 1258-1266. doi: 10.1053/jhep.2003.50451

Koniger, C., Wingert, I., Marsmann, M., Rosler, C., Beck, J., and Nassal, M. (2014). Involvement of the host DNA-repair enzyme TDP2 in formation of the covalently closed circular DNA persistence reservoir of hepatitis B viruses. Proc. Natl. Acad. Sci. U S A 111, E4244-E4253. doi: 10.1073/pnas.140998 6111

Kouwaki, T., Okamoto, T., Ito, A., Sugiyama, Y., Yamashita, K., Suzuki, T., et al. (2016). Hepatocyte Factor JMJD5 Regulates Hepatitis B Virus Replication through Interaction with HBx. J. Virol. 90, 3530-3542. doi: 10.1128/JVI.0277615

Kumar, M., Jung, S. Y., Hodgson, A. J., Madden, C. R., Qin, J., and Slagle, B. L. (2011). Hepatitis B virus regulatory $\mathrm{HBx}$ protein binds to adaptor protein IPS-1 and inhibits the activation of beta interferon. J. Virol. 85, 987-995. doi: 10.1128/JVI.01825-10

Kwon, J. A., and Rho, H. M. (2003). Transcriptional repression of the human p53 gene by hepatitis B viral core protein $(\mathrm{HBc})$ in human liver cells. Biol. Chem. 384, 203-212. doi: 10.1515/BC.2003.022 
Lambert, C., and Prange, R. (2003). Chaperone action in the posttranslational topological reorientation of the hepatitis $\mathrm{B}$ virus large envelope protein: Implications for translocational regulation. Proc. Natl. Acad. Sci. U S A 100, 5199-5204. doi: 10.1073/pnas.0930813100

Lambert, C., Doring, T., and Prange, R. (2007). Hepatitis B virus maturation is sensitive to functional inhibition of ESCRT-III, Vps4, and gamma 2-adaptin. J. Virol. 81, 9050-9060. doi: 10.1128/JVI.00479-07

Lazarus, J. V., Block, T., Brechot, C., Kramvis, A., Miller, V., Ninburg, M., et al. (2018). The hepatitis B epidemic and the urgent need for cure preparedness. Nat. Rev. Gastroenterol. Hepatol. 15, 517-518. doi: 10.1038/s41575-018-0041-6

Lee, H., Jeong, H., Lee, S. Y., Kim, S. S., and Jang, K. L. (2019). Hepatitis B Virus X Protein Stimulates Virus Replication Via DNA Methylation of the C-1619 in Covalently Closed Circular DNA. Mol. Cells 42, 67-78. doi: 10.14348/molcells. 2018.0255

Lee, S. J., Shim, H. Y., Hsieh, A., Min, J. Y., and Jung, G. (2009). Hepatitis B virus core interacts with the host cell nucleolar protein, nucleophosmin 1 . J. Microbiol. 47, 746-752. doi: 10.1007/s12275-009-2720-z

Lee, S., Kim, W., Ko, C., and Ryu, W. S. (2016). Hepatitis B virus X protein enhances Myc stability by inhibiting SCF(Skp2) ubiquitin E3 ligase-mediated Myc ubiquitination and contributes to oncogenesis. Oncogene 35, 1857-1867. doi: 10.1038/onc.2015.251

Lee, Y. H., and Yun, Y. (1998). HBx protein of hepatitis B virus activates Jak1-STAT signaling. J. Biol. Chem. 273, 25510-25515.

Levrero, M., Pollicino, T., Petersen, J., Belloni, L., Raimondo, G., and Dandri, M. (2009). Control of cccDNA function in hepatitis B virus infection. J. Hepatol. 51, 581-592. doi: 10.1016/j.jhep.2009.05.022

Li, B., Carey, M., and Workman, J. L. (2007). The role of chromatin during transcription. Cell 128, 707-719. doi: 10.1016/j.cell.2007.01.015

Li, D., Ding, J., Chen, Z., Chen, Y., Lin, N., Chen, F., et al. (2015). Accurately mapping the location of the binding site for the interaction between hepatitis B virus X protein and cytochrome c oxidase III. Int. J. Mol. Med. 35, 319-324. doi: 10.3892/ijmm.2014.2018

Li, J., He, J., Fu, Y., Hu, X., Sun, L. Q., Huang, Y., et al. (2017). Hepatitis B virus $\mathrm{X}$ protein inhibits apoptosis by modulating endoplasmic reticulum stress response. Oncotarget 8, 96027-96034. doi: 10.18632/oncotarget.21630

Li, J., Liu, Y., Wang, Z., Liu, K., Wang, Y., Liu, J., et al. (2011). Subversion of cellular autophagy machinery by hepatitis B virus for viral envelopment. J. Virol. 85, 6319-6333. doi: 10.1128/JVI.02627-10

Li, N., Zhang, L., Chen, L., Feng, W., Xu, Y., Chen, F., et al. (2012). MxA inhibits hepatitis B virus replication by interaction with hepatitis B core antigen. Hepatology 56, 803-811. doi: 10.1002/hep.25608

Li, T., Ke, Z., Liu, W., Xiong, Y., Zhu, Y., and Liu, Y. (2019). Human Hepatitis B Virus Core Protein Inhibits IFNalpha-Induced IFITM1 Expression by Interacting with BAF200. Viruses 11:11050427. doi: 10.3390/v11050427

Li, T., Yang, X., Li, W., Song, J., Li, Z., Zhu, X., et al. (2021). ADAR1 Stimulation by IFN-alpha Downregulates the Expression of MAVS via RNA Editing to Regulate the Anti-HBV Response. Mol. Ther. 29, 1335-1348. doi: 10.1016/j.ymthe.2020. 11.031

Li, Y., Sun, Y., Sun, F., Hua, R., Li, C., Chen, L., et al. (2018). Mechanisms and Effects on HBV Replication of the Interaction between HBV Core Protein and Cellular Filamin B. Virol. Sin. 33, 162-172. doi: 10.1007/s12250-018-0023-4

Liang, T. J., Block, T. M., Mcmahon, B. J., Ghany, M. G., Urban, S., Guo, J. T., et al. (2015). Present and future therapies of hepatitis B: From discovery to cure. Hepatology 62, 1893-1908. doi: 10.1002/hep.28025

Lieberman, P. M. (2016). Epigenetics and Genetics of Viral Latency. Cell Host Microbe 19, 619-628. doi: 10.1016/j.chom.2016.04.008

Lim, K. H., Kim, K. H., Choi, S. I., Park, E. S., Park, S. H., Ryu, K., et al. (2011). RPS3a over-expressed in HBV-associated hepatocellular carcinoma enhances the $\mathrm{HBx}$-induced NF-kappaB signaling via its novel chaperoning function. PLoS One 6:e22258. doi: 10.1371/journal.pone.0022258

Lin, J., Gu, C., Shen, Z., Liu, Y., Wang, W., Tao, S., et al. (2017). Hepatocyte nuclear factor lalpha downregulates HBV gene expression and replication by activating the NF-kappaB signaling pathway. PLoS One 12:e0174017. doi: 10.1371/journal. pone. 0174017

Lin, S. M., Cheng, J., Lu, Y. Y., Zhang, S. L., Yang, Q., Chen, T. Y., et al. (2006). Screening and identification of interacting proteins with hepatitis B virus core protein in leukocytes and cloning of new gene C1. World J. Gastroenterol. 12, 1043-1048. doi: 10.3748/wjg.v12.i7.1043
Lin, W. S., Jiao, B. Y., Wu, Y. L., Chen, W. N., and Lin, X. (2012). Hepatitis B virus $\mathrm{X}$ protein blocks filamentous actin bundles by interaction with eukaryotic translation elongat ion factor 1 alpha 1. J. Med. Virol. 84, 871-877. doi: 10.1002/ jmv.23283

Lin, Y., Nomura, T., Cheong, J., Dorjsuren, D., Iida, K., and Murakami, S. (1997). Hepatitis B virus $\mathrm{X}$ protein is a transcriptional modulator that communicates with transcription factor IIB and the RNA polymerase II subunit 5. J. Biol. Chem. 272, 7132-7139.

Ling, M. T., Chiu, Y. T., Lee, T. K., Leung, S. C., Fung, M. K., Wang, X., et al. (2008). Id-1 induces proteasome-dependent degradation of the HBX protein. J. Mol. Biol. 382, 34-43. doi: 10.1016/j.jmb.2007.06.020

Liu, B., Fang, M., He, Z., Cui, D., Jia, S., Lin, X., et al. (2015). Hepatitis B virus stimulates G6PD expression through HBx-mediated Nrf2 activation. Cell Death Dis. 6:e1980. doi: 10.1038/cddis.2015.322

Liu, C., Cai, D., Zhang, L., Tang, W., Yan, R., Guo, H., et al. (2016). Identification of hydrolyzable tannins (punicalagin, punicalin and geraniin) as novel inhibitors of hepatitis B virus covalently closed circular DNA. Antiviral. Res. 134, 97-107. doi: 10.1016/j.antiviral.2016.08.026

Liu, H., Lou, G., Li, C., Wang, X., Cederbaum, A. I., Gan, L., et al. (2014). HBx inhibits CYP2E1 gene expression via downregulating HNF4alpha in human hepatoma cells. PLoS One 9:e107913. doi: 10.1371/journal.pone.0107913

Liu, H., Xi, J., and Hu, J. (2021). Regulation of Hepatitis B Virus Replication by Cyclin Docking Motifs in Core Protein. J. Virol. 95:21. doi: 10.1128/JVI.0023021

Liu, H., Yuan, Y., Guo, H., Mitchelson, K., Zhang, K., Xie, L., et al. (2012). Hepatitis B virus encoded X protein suppresses apoptosis by inhibition of the caspase-independent pathway. J. Proteome Res. 11, 4803-4813. doi: 10.1021/ pr2012297

Liu, K., Qian, L., Wang, J., Li, W., Deng, X., Chen, X., et al. (2009). Twodimensional blue native/SDS-PAGE analysis reveals heat shock protein chaperone machinery involved in hepatitis B virus production in HepG2.2.15 cells. Mol. Cell Proteomics 8, 495-505. doi: 10.1074/mcp.M800250-MCP200

Liu, N., Zhang, J., Yang, X., Jiao, T., Zhao, X., Li, W., et al. (2017). HDM2 Promotes NEDDylation of Hepatitis B Virus HBx To Enhance Its Stability and Function. J. Virol. 91, 340-317. doi: 10.1128/JVI.00340-17

Liu, X. Y., Tang, S. H., Wu, S. L., Luo, Y. H., Cao, M. R., Zhou, H. K., et al. (2015). Epigenetic modulation of insulin-like growth factor-II overexpression by hepatitis B virus X protein in hepatocellular carcinoma. Am. J. Cancer Res. 5, 956-978.

Loffler-Mary, H., Dumortier, J., Klentsch-Zimmer, C., and Prange, R. (2000). Hepatitis B virus assembly is sensitive to changes in the cytosolic S loop of the envelope proteins. Virology 270, 358-367. doi: 10.1006/viro.2000.0268

Loffler-Mary, H., Werr, M., and Prange, R. (1997). Sequence-specific repression of cotranslational translocation of the hepatitis $\mathrm{B}$ virus envelope proteins coincides with binding of heat shock protein Hsc70. Virology 235, 144-152. doi: 10.1006/ viro.1997.8689

Long, Q., Yan, R., Hu, J., Cai, D., Mitra, B., Kim, E. S., et al. (2017). The role of host DNA ligases in hepadnavirus covalently closed circular DNA formation. PLoS Pathog. 13:e1006784. doi: 10.1371/journal.ppat.1006784

Lott, L., Beames, B., Notvall, L., and Lanford, R. E. (2000). Interaction between hepatitis B virus core protein and reverse transcriptase. J. Virol. 74, 1147911489. doi: 10.1128/jvi.74.24.11479-11489.2000

Lu, Y. Y., Cheng, J., Yang, Y. P., Liu, Y., Wang, L., Li, K., et al. (2005). Cloning and characterization of a novel hepatitis $\mathrm{B}$ virus core binding protein C12. World J. Gastroenterol. 11, 5666-5671. doi: 10.3748/wjg.v11.i36. 5666

Lu, Z. P., Xiao, Z. L., Yang, Z., Li, J., Feng, G. X., Chen, F. Q., et al. (2015). Hepatitis $\mathrm{B}$ virus $\mathrm{X}$ protein promotes human hepatoma cell growth via upregulation of transcription factor AP2alpha and sphingosine kinase 1. Acta Pharmacol. Sin. 36, 1228-1236. doi: 10.1038/aps.2015.38

Luber, B., Lauer, U., Weiss, L., Hohne, M., Hofschneider, P. H., and Kekule, A. S. (1993). The hepatitis B virus transactivator $\mathrm{HBx}$ causes elevation of diacylglycerol and activation of protein kinase C. Res. Virol. 144, 311-321.

Lubyova, B., Hodek, J., Zabransky, A., Prouzova, H., Hubalek, M., Hirsch, I., et al. (2017). PRMT5: A novel regulator of Hepatitis B virus replication and an arginine methylase of HBV core. PLoS One 12:e0186982. doi: 10.1371/journal. pone. 0186982 
Lucifora, J., Esser, K., and Protzer, U. (2013). Ezetimibe blocks hepatitis B virus infection after virus uptake into hepatocytes. Antiviral. Res. 97, 195-197. doi: 10.1016/j.antiviral.2012.12.008

Lucifora, J., Xia, Y., Reisinger, F., Zhang, K., Stadler, D., Cheng, X., et al. (2014). Specific and nonhepatotoxic degradation of nuclear hepatitis B virus cccDNA. Science 343, 1221-1228. doi: 10.1126/science.1243462

Ludgate, L., Adams, C., and Hu, J. (2011). Phosphorylation state-dependent interactions of hepadnavirus core protein with host factors. PLoS One 6:e29566. doi: 10.1371/journal.pone.0029566

Luo, X., Huang, Y., Chen, Y., Tu, Z., Hu, J., Tavis, J. E., et al. (2016). Association of Hepatitis B Virus Covalently Closed Circular DNA and Human APOBEC3B in Hepatitis B Virus-Related Hepatocellular Carcinoma. PLoS One 11:e0157708. doi: 10.1371/journal.pone.0157708

Lv, M., Zhang, B., Shi, Y., Han, Z., Zhang, Y., Zhou, Y., et al. (2015). Identification of BST-2/tetherin-induced hepatitis B virus restriction and hepatocyte-specific BST-2 inactivation. Sci. Rep. 5:11736. doi: 10.1038/srep11736

Lwa, S. H., and Chen, W. N. (2005). Hepatitis B virus X protein interacts with beta5 subunit of heterotrimeric guanine nucleotide binding protein. Virol. J. 2:76. doi: 10.1186/1743-422X-2-76

Lythgoe, K. A., Lumley, S. F., Pellis, L., Mckeating, J. A., and Matthews, P. C. (2021). Estimating hepatitis B virus cccDNA persistence in chronic infection. Virus Evol. 7:veaa063. doi: 10.1093/ve/veaa063

Macovei, A., Petrareanu, C., Lazar, C., Florian, P., and Branza-Nichita, N. (2013). Regulation of hepatitis B virus infection by Rab5, Rab7, and the endolysosomal compartment. J. Virol. 87, 6415-6427. doi: 10.1128/JVI.00393-13

Macovei, A., Radulescu, C., Lazar, C., Petrescu, S., Durantel, D., Dwek, R. A., et al. (2010). Hepatitis B virus requires intact caveolin-1 function for productive infection in HepaRG cells. J. Virol. 84, 243-253. doi: 10.1128/JVI.01207-09

Maguire, H. F., Hoeffler, J. P., and Siddiqui, A. (1991). HBV X protein alters the DNA binding specificity of CREB and ATF-2 by protein-protein interactions. Science 252, 842-844. doi: 10.1126/science.1827531

Makokha, G. N., Abe-Chayama, H., Chowdhury, S., Hayes, C. N., Tsuge, M., Yoshima, T., et al. (2019). Regulation of the Hepatitis B virus replication and gene expression by the multi-functional protein TARDBP. Sci. Rep. 9:8462. doi: 10.1038/s41598-019-44934-5

Minor, M. M., Hollinger, F. B., Mcnees, A. L., Jung, S. Y., Jain, A., Hyser, J. M., et al. (2020). Hepatitis B Virus HBx Protein Mediates the Degradation of Host Restriction Factors through the Cullin 4 DDB1 E3 Ubiquitin Ligase Complex. Cells 9:9040834. doi: 10.3390/cells9040834

Molina-Jimenez, F., Benedicto, I., Murata, M., Martin-Vilchez, S., Seki, T., Antonio Pintor-Toro, J., et al. (2010). Expression of pituitary tumor-transforming gene 1 (PTTG1)/securin in hepatitis B virus (HBV)-associated liver diseases: evidence for an HBV X protein-mediated inhibition of PTTG1 ubiquitination and degradation. Hepatology 51, 777-787. doi: 10.1002/hep.23468

Mueller, H., Lopez, A., Tropberger, P., Wildum, S., Schmaler, J., Pedersen, L., et al. (2019). PAPD5/7 Are Host Factors That Are Required for Hepatitis B Virus RNA Stabilization. Hepatology 69, 1398-1411. doi: 10.1002/hep.30329

Mukherji, A., Janbandhu, V. C., and Kumar, V. (2007). HBx-dependent cell cycle deregulation involves interaction with cyclin E/A-cdk2 complex and destabilization of p27Kip1. Biochem. J. 401, 247-256. doi: 10.1042/BJ20061091

Murphy, C. M., Xu, Y., Li, F., Nio, K., Reszka-Blanco, N., Li, X., et al. (2016). Hepatitis B Virus X Protein Promotes Degradation of SMC5/6 to Enhance HBV Replication. Cell Rep. 16, 2846-2854. doi: 10.1016/j.celrep.2016.08.026

Na, T. Y., Ka, N. L., Rhee, H., Kyeong, D., Kim, M. H., Seong, J. K., et al. (2016). Interaction of hepatitis $\mathrm{B}$ virus $\mathrm{X}$ protein with PARP1 results in inhibition of DNA repair in hepatocellular carcinoma. Oncogene 35, 5435-5445. doi: 10. 1038/onc.2016.82

Newbold, J. E., Xin, H., Tencza, M., Sherman, G., Dean, J., Bowden, S., et al. (1995). The covalently closed duplex form of the hepadnavirus genome exists in situ as a heterogeneous population of viral minichromosomes. J. Virol. 69, 3350-3357.

Nguyen, D. H., Gummuluru, S., and Hu, J. (2007). Deamination-independent inhibition of hepatitis B virus reverse transcription by APOBEC3G. J. Virol. 81, 4465-4472. doi: 10.1128/JVI.02510-06

Nguyen, D. H., Ludgate, L., and Hu, J. (2008). Hepatitis B virus-cell interactions and pathogenesis. J. Cell Physiol. 216, 289-294. doi: 10.1002/jcp.21416

Niu, C., Livingston, C. M., Li, L., Beran, R. K., Daffis, S., Ramakrishnan, D., et al. (2017). The Smc5/6 Complex Restricts HBV when Localized to ND10 without Inducing an Innate Immune Response and Is Counteracted by the HBV X
Protein Shortly after Infection. PLoS One 12:e0169648. doi: 10.1371/journal. pone.0169648

Niu, Y., Wu, Z., Shen, Q., Song, J., Luo, Q., You, H., et al. (2013). Hepatitis B virus $\mathrm{X}$ protein co-activates pregnane $\mathrm{X}$ receptor to induce the cytochrome $\mathrm{P} 450$ 3A4 enzyme, a potential implication in hepatocarcinogenesis. Dig. Liver Dis. 45, 1041-1048. doi: 10.1016/j.dld.2013.06.004

Niu, Y., Xu, M., Slagle, B. L., Huang, H., Li, S., Guo, G. L., et al. (2017). Farnesoid $\mathrm{X}$ receptor ablation sensitizes mice to hepatitis $\mathrm{b}$ virus $\mathrm{X}$ protein-induced hepatocarcinogenesis. Hepatology 65, 893-906. doi: 10.1002/hep.28924

Nkongolo, S., Ni, Y., Lempp, F. A., Kaufman, C., Lindner, T., Esser-Nobis, K., et al. (2014). Cyclosporin A inhibits hepatitis B and hepatitis D virus entry by cyclophilin-independent interference with the NTCP receptor. J. Hepatol. 60 , 723-731. doi: 10.1016/j.jhep.2013.11.022

Nkongolo, S., Nussbaum, L., Lempp, F. A., Wodrich, H., Urban, S., and Ni, Y. (2019). The retinoic acid receptor (RAR) alpha-specific agonist Am80 (tamibarotene) and other RAR agonists potently inhibit hepatitis B virus transcription from cccDNA. Antiviral. Res. 168, 146-155. doi: 10.1016/j. antiviral.2019.04.009

Ohno, H., Kaneko, S., Lin, Y., Kobayashi, K., and Murakami, S. (1999). Human hepatitis B virus X protein augments the DNA binding of nuclear factor for IL-6 through its basic-leucine zipper domain. J. Med. Virol. 58, 11-18.

Ori, A., Atzmony, D., Haviv, I., and Shaul, Y. (1994). An NF1 motif plays a central role in hepatitis B virus enhancer. Virology 204, 600-608. doi: 10.1006/viro. 1994.1574

Osseman, Q., Gallucci, L., Au, S., Cazenave, C., Berdance, E., Blondot, M. L., et al. (2018). The chaperone dynein LL1 mediates cytoplasmic transport of empty and mature hepatitis B virus capsids. J. Hepatol. 68, 441-448. doi: 10.1016/j. jhep.2017.10.032

Pang, R., Lee, T. K., Poon, R. T., Fan, S. T., Wong, K. B., Kwong, Y. L., et al. (2007). Pin1 interacts with a specific serine-proline motif of hepatitis B virus $\mathrm{X}$-protein to enhance hepatocarcinogenesis. Gastroenterology 132, 1088-1103. doi: $10.1053 /$ j.gastro.2006.12.030

Pante, N., and Kann, M. (2002). Nuclear pore complex is able to transport macromolecules with diameters of about $39 \mathrm{~nm}$. Mol. Biol. Cell 13, 425-434. doi: 10.1091/mbc.01-06-0308

Pei, D. Q., and Shih, C. H. (1990). Transcriptional activation and repression by cellular DNA-binding protein C/EBP. J. Virol. 64, 1517-1522.

Phillips, S., Chokshi, S., Chatterji, U., Riva, A., Bobardt, M., Williams, R., et al. (2015). Alisporivir inhibition of hepatocyte cyclophilins reduces HBV replication and hepatitis B surface antigen production. Gastroenterology 148, 403-414e407. doi: 10.1053/j.gastro.2014.10.004

Pollicino, T., Belloni, L., Raffa, G., Pediconi, N., Squadrito, G., Raimondo, G., et al. (2006). Hepatitis B virus replication is regulated by the acetylation status of hepatitis B virus cccDNA-bound H3 and H4 histones. Gastroenterology 130, 823-837. doi: 10.1053/j.gastro.2006.01.001

Qadri, I., Fatima, K., and Abde, L. H. H. (2011). Hepatitis B virus X protein impedes the DNA repair via its association with transcription factor, TFIIH. BMC Microbiol. 11:48. doi: 10.1186/1471-2180-11-48

Qadri, I., Maguire, H. F., and Siddiqui, A. (1995). Hepatitis B virus transactivator protein X interacts with the TATA-binding protein. Proc. Natl. Acad. Sci. U S A 92, 1003-1007. doi: 10.1073/pnas.92.4.1003

Qi, Y., Gao, Z., Xu, G., Peng, B., Liu, C., Yan, H., et al. (2016). DNA Polymerase kappa Is a Key Cellular Factor for the Formation of Covalently Closed Circular DNA of Hepatitis B Virus. PLoS Pathog. 12:e1005893. doi: 10.1371/journal.ppat. 1005893

Qian, G., Hu, B., Zhou, D., Xuan, Y., Bai, L., and Duan, C. (2015). NIRF, a Novel Ubiquitin Ligase, Inhibits Hepatitis B Virus Replication Through Effect on HBV Core Protein and H3 Histones. DNA Cell Biol. 34, 327-332. doi: 10.1089/dna. 2014.2714

Qian, G., Jin, F., Chang, L., Yang, Y., Peng, H., and Duan, C. (2012). NIRF, a novel ubiquitin ligase, interacts with hepatitis B virus core protein and promotes its degradation. Biotechnol. Lett. 34, 29-36. doi: 10.1007/s10529-011-0751-0

Qiao, Y., Han, X., Guan, G., Wu, N., Sun, J., Pak, V., et al. (2016). TGF-beta triggers HBV cccDNA degradation through AID-dependent deamination. FEBS Lett. 590, 419-427. doi: 10.1002/1873-3468.12058

Qin, D., Li, K., Qu, J., Wang, S., Zou, C., Sheng, Y., et al. (2013). HBx and HBs regulate RhoC expression by upregulating transcription factor Ets-1. Arch. Virol. 158, 1773-1781. doi: 10.1007/s00705-013-1655-1 
Quarleri, J. (2014). Core promoter: a critical region where the hepatitis B virus makes decisions. World J. Gastroenterol. 20, 425-435. doi: 10.3748/wjg.v20.i2.425

Quasdorff, M., and Protzer, U. (2010). Control of hepatitis B virus at the level of transcription. J. Viral. Hepat. 17, 527-536. doi: 10.1111/j.1365-2893.2010. 01315.x

Rahmani, Z., Huh, K. W., Lasher, R., and Siddiqui, A. (2000). Hepatitis B virus $\mathrm{X}$ protein colocalizes to mitochondria with a human voltage-dependent anion channel, HVDAC3, and alters its transmembrane potential. J. Virol. 74, 28402846.

Rawat, S., and Bouchard, M. J. (2015). The hepatitis B virus (HBV) HBx protein activates AKT to simultaneously regulate $\mathrm{HBV}$ replication and hepatocyte survival. J. Virol. 89, 999-1012. doi: 10.1128/JVI.02440-14

Razanskas, R., and Sasnauskas, K. (2010). Interaction of hepatitis B virus core protein with human GIPC1. Arch. Virol. 155, 247-250. doi: 10.1007/s00705009-0561-z

Ren, J. H., Hu, J. L., Cheng, S. T., Yu, H. B., Wong, V. K. W., Law, B. Y. K., et al. (2018). SIRT3 restricts hepatitis B virus transcription and replication through epigenetic regulation of covalently closed circular DNA involving suppressor of variegation 3-9 homolog 1 and SET domain containing 1A histone methyltransferases. Hepatology 68, 1260-1276. doi: 10.1002/hep.29912

Ren, J. H., Tao, Y., Zhang, Z. Z., Chen, W. X., Cai, X. F., Chen, K., et al. (2014). Sirtuin 1 regulates hepatitis $\mathrm{B}$ virus transcription and replication by targeting transcription factor AP-1. J. Virol. 88, 2442-2451. doi: 10.1128/JVI.02861-13

Riviere, L., Gerossier, L., Ducroux, A., Dion, S., Deng, Q., Michel, M. L., et al. (2015). HBx relieves chromatin-mediated transcriptional repression of hepatitis B viral cccDNA involving SETDB1 histone methyltransferase. J. Hepatol. 63, 1093-1102. doi: 10.1016/j.jhep.2015.06.023

Rost, M., Mann, S., Lambert, C., Doring, T., Thome, N., and Prange, R. (2006). Gamma-adaptin, a novel ubiquitin-interacting adaptor, and Nedd4 ubiquitin ligase control hepatitis B virus maturation. J. Biol. Chem. 281, 29297-29308. doi: 10.1074/jbc.M603517200

Rui, E., Moura, P. R., Goncalves, K. A., Rooney, R. J., and Kobarg, J. (2006). Interaction of the hepatitis $\mathrm{B}$ virus protein $\mathrm{HBx}$ with the human transcription regulatory protein p120E4F in vitro. Virus Res. 115, 31-42. doi: 10.1016/j. virusres.2005.07.003

Saeed, U., Kim, J., Piracha, Z. Z., Kwon, H., Jung, J., Chwae, Y. J., et al. (2018). Parvulin 14 and parvulin 17 bind to $\mathrm{HBx}$ and cccDNA and upregulate HBV replication from cccDNA to virion in a HBx-dependent manner. J. Virol. 2018:18. doi: 10.1128/JVI.01840-18

Salerno, D., Chiodo, L., Alfano, V., Floriot, O., Cottone, G., Paturel, A., et al. (2020). Hepatitis B protein HBx binds the DLEU2 lncRNA to sustain cccDNA and host cancer-related gene transcription. Gut 69, 2016-2024. doi: 10.1136/gutjnl2019-319637

Saracco, G., Rizzetto, M., and Verme, G. (1994). Interferon in chronic hepatitis B. Antiviral. Res. 24, 137-143. doi: 10.1016/0166-3542(94)90062-0

Saxena, N., and Kumar, V. (2014). The HBx oncoprotein of hepatitis B virus deregulates the cell cycle by promoting the intracellular accumulation and re-compartmentalization of the cellular deubiquitinase USP37. PLoS One 9:e111256. doi: 10.1371/journal.pone.0111256

Schmitz, A., Schwarz, A., Foss, M., Zhou, L., Rabe, B., Hoellenriegel, J., et al. (2010). Nucleoporin 153 arrests the nuclear import of hepatitis B virus capsids in the nuclear basket. PLoS Pathog. 6:e1000741. doi: 10.1371/journal.ppat.10 00741

Schreiner, S., and Nassal, M. (2017). A Role for the Host DNA Damage Response in Hepatitis B Virus cccDNA Formation-and Beyond? Viruses 9:9050125. doi: 10.3390/v9050125

Schulze, A., Gripon, P., and Urban, S. (2007). Hepatitis B virus infection initiates with a large surface protein-dependent binding to heparan sulfate proteoglycans. Hepatology 46, 1759-1768. doi: 10.1002/hep.21896

Schulze, A., Schieck, A., Ni, Y., Mier, W., and Urban, S. (2010). Fine mapping of pre-S sequence requirements for hepatitis $B$ virus large envelope protein-mediated receptor interaction. J. Virol. 84, 1989-2000. doi: 10.1128/JVI.01902-09

Schweitzer, A., Horn, J., Mikolajczyk, R. T., Krause, G., and Ott, J. J. (2015). Estimations of worldwide prevalence of chronic hepatitis $\mathrm{B}$ virus infection: a systematic review of data published between 1965 and 2013. Lancet 386, 1546-1555. doi: 10.1016/S0140-6736(15)61412-X
Sekiba, K., Otsuka, M., Ohno, M., Yamagami, M., Kishikawa, T., Seimiya, T., et al. (2019b). Pevonedistat, a Neuronal Precursor Cell-Expressed Developmentally Down-Regulated Protein 8-Activating Enzyme Inhibitor, Is a Potent Inhibitor of Hepatitis B Virus. Hepatology 69, 1903-1915. doi: 10.1002/hep.30491

Sekiba, K., Otsuka, M., Ohno, M., Yamagami, M., Kishikawa, T., Suzuki, T., et al. (2019a). Inhibition of HBV Transcription From cccDNA With Nitazoxanide by Targeting the HBx-DDB1 Interaction. Cell Mol. Gastroenterol. Hepatol. 7, 297-312. doi: 10.1016/j.jcmgh.2018.10.010

Selzer, L., and Zlotnick, A. (2015). Assembly and Release of Hepatitis B Virus. Cold Spring Harb. Perspect. Med. 5:21394. doi: 10.1101/cshperspect.a021394

Seo, H. W., Seo, J. P., and Jung, G. (2018). Heat shock protein 70 and heat shock protein 90 synergistically increase hepatitis B viral capsid assembly. Biochem. Biophys. Res. Commun. 503, 2892-2898. doi: 10.1016/j.bbrc.2018.08.065

Sheraz, M., Cheng, J., Tang, L., Chang, J., and Guo, J. T. (2019). Cellular DNA Topoisomerases Are Required for the Synthesis of Hepatitis B Virus Covalently Closed Circular DNA. J. Virol. 93:2218. doi: 10.1128/JVI.02230-18

Shi, Y., Zhang, H., Han, Z., Mi, X., Zhang, W., and Lv, M. (2016). HBx interacted with Smad4 to deprive activin a growth inhibition function in hepatocyte HL7702 on CRM1 manner. Tumour Biol. 37, 3405-3415. doi: 10.1007/s13277015-4076-9

Shim, H. Y., Quan, X., Yi, Y. S., and Jung, G. (2011). Heat shock protein 90 facilitates formation of the HBV capsid via interacting with the HBV core protein dimers. Virology 410, 161-169. doi: 10.1016/j.virol.2010.11.005

Shimura, S., Watashi, K., Fukano, K., Peel, M., Sluder, A., Kawai, F., et al. (2017). Cyclosporin derivatives inhibit hepatitis B virus entry without interfering with NTCP transporter activity. J. Hepatol. 66, 685-692. doi: 10.1016/j.jhep.2016.11.009

Shin, G. C., Ahn, S. H., Choi, H. S., Lim, K. H., Choi, D. Y., Kim, K. P., et al. (2013). Hepatocystin/80K-H inhibits replication of hepatitis B virus through interaction with $\mathrm{HBx}$ protein in hepatoma cell. Biochim. Biophys. Acta 1832, 1569-1581. doi: 10.1016/j.bbadis.2013.04.026

Shon, J. K., Shon, B. H., Park, I. Y., Lee, S. U., Fa, L., Chang, K. Y., et al. (2009). Hepatitis B virus-X protein recruits histone deacetylase 1 to repress insulinlike growth factor binding protein 3 transcription. Virus Res. 139, 14-21. doi: 10.1016/j.virusres.2008.09.006

Shukla, R., Yue, J., Siouda, M., Gheit, T., Hantz, O., Merle, P., et al. (2011). Proinflammatory cytokine TNF-alpha increases the stability of hepatitis B virus $\mathrm{X}$ protein through NF-kappaB signaling. Carcinogenesis 32, 978-985. doi: 10. 1093/carcin/bgr057

Sohn, S. Y., Kim, S. B., Kim, J., and Ahn, B. Y. (2006). Negative regulation of hepatitis B virus replication by cellular Hsp40/DnaJ proteins through destabilization of viral core and X proteins. J. Gen. Virol. 87, 1883-1891. doi: 10.1099/vir.0.81684-0

Srisuttee, R., Koh, S. S., Kim, S. J., Malilas, W., Boonying, W., Cho, I. R., et al. (2012). Hepatitis B virus X (HBX) protein upregulates beta-catenin in a human hepatic cell line by sequestering SIRT1 deacetylase. Oncol. Rep. 28, 276-282. doi: $10.3892 /$ or. 2012.1798

Stavrou, S., and Ross, S. R. (2015). APOBEC3 Proteins in Viral Immunity. J. Immunol. 195, 4565-4570. doi: 10.4049/jimmunol.1501504

Su, Z. J., Cao, J. S., Wu, Y. F., Chen, W. N., Lin, X., Wu, Y. L., et al. (2017). Deubiquitylation of hepatitis $B$ virus $X$ protein $(\mathrm{HBx})$ by ubiquitin-specific peptidase 15 (USP15) increases HBx stability and its transactivation activity. Sci. Rep. 7:40246. doi: 10.1038/srep40246

Summers, J., O'connell, A., and Millman, I. (1975). Genome of hepatitis B virus: restriction enzyme cleavage and structure of DNA extracted from Dane particles. Proc. Natl. Acad. Sci. U S A 72, 4597-4601.

Summers, J., Smith, P. M., and Horwich, A. L. (1990). Hepadnavirus envelope proteins regulate covalently closed circular DNA amplification. J. Virol. 64, 2819-2824.

Tacke, F., Liedtke, C., Bocklage, S., Manns, M. P., and Trautwein, C. (2005). CREB/PKA sensitive signalling pathways activate and maintain expression levels of the hepatitis B virus pre-S2/S promoter. Gut 54, 1309-1317. doi: 10.1136/gut.2005.065086

Tan, T. L., Fang, N., Neo, T. L., Singh, P., Zhang, J., Zhou, R., et al. (2008). Rac1 GTPase is activated by hepatitis B virus replication-involvement of HBX. Biochim. Biophys. Acta 1783, 360-374. doi: 10.1016/j.bbamcr.2007.10.024

Tan, T. L., Feng, Z., Lu, Y. W., Chan, V., and Chen, W. N. (2006). Adhesion contact kinetics of HepG2 cells during Hepatitis B virus replication: Involvement of 
SH3-binding motif in HBX. Biochim. Biophys. Acta 1762, 755-766. doi: 10.1016/ j.bbadis.2006.06.016

Tan, Z., Pionek, K., Unchwaniwala, N., Maguire, M. L., Loeb, D. D., and Zlotnick, A. (2015). The interface between hepatitis B virus capsid proteins affects selfassembly, pregenomic RNA packaging, and reverse transcription. J. Virol 89, 3275-3284. doi: 10.1128/JVI.03545-14

Tanaka, Y., Kanai, F., Ichimura, T., Tateishi, K., Asaoka, Y., Guleng, B., et al. (2006). The hepatitis B virus $\mathrm{X}$ protein enhances AP- 1 activation through interaction with Jab1. Oncogene 25, 633-642. doi: 10.1038/sj.onc.1209093

Tanaka, Y., Kanai, F., Kawakami, T., Tateishi, K., Ijichi, H., Kawabe, T., et al. (2004). Interaction of the hepatitis $\mathrm{B}$ virus $\mathrm{X}$ protein $(\mathrm{HBx})$ with heat shock protein 60 enhances HBx-mediated apoptosis. Biochem. Biophys. Res. Commun. 318, 461-469. doi: 10.1016/j.bbrc.2004.04.046

Tang, H. M., Gao, W. W., Chan, C. P., Cheng, Y., Chaudhary, V., Deng, J. J., et al. (2014). Requirement of CRTC1 coactivator for hepatitis B virus transcription. Nucleic Acids Res. 42, 12455-12468. doi: 10.1093/nar/gku925

Tang, Y., Zhang, Y., Wang, C., Sun, Z., Li, L., Dong, J., et al. (2018). 14-3-3zeta binds to hepatitis B virus protein $X$ and maintains its protein stability in hepatocellular carcinoma cells. Cancer Med. 7, 5543-5553. doi: 10.1002/cam4.1512

Tian, X., Zhao, C., Zhu, H., She, W., Zhang, J., Liu, J., et al. (2010). Hepatitis B virus (HBV) surface antigen interacts with and promotes cyclophilin a secretion: possible link to pathogenesis of HBV infection. J. Virol. 84, 3373-3381. doi: 10.1128/JVI.02555-09

Tian, X., Zhao, F., Sun, W., Zhi, X., Cheng, Z., Zhou, M., et al. (2014). CRTC2 enhances HBV transcription and replication by inducing PGC1alpha expression. Virol. J. 11:30. doi: 10.1186/1743-422X-11-30:10.1186/1743-422X11-30

Tokusumi, Y., Zhou, S., and Takada, S. (2004). Nuclear respiratory factor 1 plays an essential role in transcriptional initiation from the hepatitis B virus $\mathrm{x}$ gene promoter. J. Virol. 78, 10856-10864. doi: 10.1128/JVI.78.20.10856-10864.2004

Tropberger, P., Mercier, A., Robinson, M., Zhong, W., Ganem, D. E., and Holdorf, M. (2015). Mapping of histone modifications in episomal HBV cccDNA uncovers an unusual chromatin organization amenable to epigenetic manipulation. Proc. Natl. Acad. Sci. U S A 112, E5715-E5724. doi: 10.1073/pnas. 1518090112

Tuttleman, J. S., Pourcel, C., and Summers, J. (1986). Formation of the pool of covalently closed circular viral DNA in hepadnavirus-infected cells. Cell 47, $451-460$.

Umetsu, T., Inoue, J., Kogure, T., Kakazu, E., Ninomiya, M., Iwata, T., et al. (2018). Inhibitory effect of silibinin on hepatitis B virus entry. Biochem. Biophys. Rep. 14, 20-25. doi: 10.1016/j.bbrep.2018.03.003

Vandenbossche, J., Jessner, W., Van Den Boer, M., Biewenga, J., Berke, J. M., Talloen, W., et al. (2019). Pharmacokinetics, Safety and Tolerability of JNJ56136379, a Novel Hepatitis B Virus Capsid Assembly Modulator, in Healthy Subjects. Adv. Ther. 36, 2450-2462. doi: 10.1007/s12325-019-01017-1

Voss, T. C., and Hager, G. L. (2014). Dynamic regulation of transcriptional states by chromatin and transcription factors. Nat. Rev. Genet. 15, 69-81. doi: 10.1038/ $\operatorname{nrg} 3623$

Wang, J., Jia, J., Chen, R., Ding, S., Xu, Q., Zhang, T., et al. (2018). RFX1 participates in doxorubicin-induced hepatitis B virus reactivation. Cancer Med. 7, 2021-2033. doi: 10.1002/cam4.1468

Wang, L. Z., Qihui, Z., Jing, Y., Zhipeng, F., Andrew, Y., and John, G. (2019). PS074-A first-in-class orally available HBV cccDNA destabilizer ccc_R08 achieved sustainable HBsAg and HBV DNA suppression in the HBV circle mouse model through elimination of cccDNA-like molecules in the mouse liver. J. Hepatol. 70:e48. doi: 10.1016/S0618-8278(19)30086-6

Wang, X., Li, Y., Mao, A., Li, C., Li, Y., and Tien, P. (2010). Hepatitis B virus $\mathrm{X}$ protein suppresses virus-triggered IRF3 activation and IFN-beta induction by disrupting the VISA-associated complex. Cell Mol. Immunol. 7, 341-348. doi: $10.1038 / \mathrm{cmi} .2010 .36$

Wang, X., Zhou, Y., Sun, L., Chen, W., Li, X., Wang, Q., et al. (2008). Complex formation between heat shock protein 72 and hepatitis B virus X protein in hepatocellular carcinoma tissues. J. Proteome Res. 7, 5133-5137. doi: 10.1021/ pr800435g

Wang, Y. P., Liu, F., He, H. W., Han, Y. X., Peng, Z. G., Li, B. W., et al. (2010). Heat stress cognate 70 host protein as a potential drug target against drug resistance in hepatitis B virus. Antimicrob. Agents Chemother. 54, 2070-2077. doi: 10.1128/AAC.01764-09
Wang, Y., Cai, J., Zeng, X., Chen, Y., Yan, W., Ouyang, Y., et al. (2015). Downregulation of toll-like receptor 4 induces suppressive effects on hepatitis $\mathrm{B}$ virus-related hepatocellular carcinoma via ERK1/2 signaling. BMC Cancer 15:821. doi: 10.1186/s12885-015-1866-9

Wang, Y., Han, M., Liu, S., Yuan, X., Zhao, J., Lu, H., et al. (2021). S6K1 inhibits HBV replication through inhibiting AMPK-ULK1 pathway and disrupting acetylation modification of H3K27. Life Sci. 265:118848. doi: 10.1016/j.lfs.2020. 118848

Waris, G., Huh, K. W., and Siddiqui, A. (2001). Mitochondrially associated hepatitis B virus X protein constitutively activates transcription factors STAT3 and NF-kappa B via oxidative stress. Mol. Cell Biol. 21, 7721-7730. doi: 10.1128/MCB.21.22.7721-7730.2001

Watanabe, T., Sorensen, E. M., Naito, A., Schott, M., Kim, S., and Ahlquist, P. (2007). Involvement of host cellular multivesicular body functions in hepatitis B virus budding. Proc. Natl. Acad. Sci. U S A 104, 10205-10210. doi: 10.1073/ pnas. 0704000104

Watashi, K., Urban, S., Li, W., and Wakita, T. (2014). NTCP and beyond: opening the door to unveil hepatitis B virus entry. Int. J. Mol. Sci. 15, 2892-2905. doi: 10.3390/ijms15022892

Wei, L., and Ploss, A. (2020). Core components of DNA lagging strand synthesis machinery are essential for hepatitis B virus cccDNA formation. Nat. Microbiol. 5, 715-726. doi: 10.1038/s41564-020-0678-0

Wen, Y., Golubkov, V. S., Strongin, A. Y., Jiang, W., and Reed, J. C. (2008). Interaction of hepatitis B viral oncoprotein with cellular target HBXIP dysregulates centrosome dynamics and mitotic spindle formation. J. Biol. Chem. 283, 2793-2803. doi: 10.1074/jbc.M708419200

Werle-Lapostolle, B., Bowden, S., Locarnini, S., Wursthorn, K., Petersen, J., Lau, G., et al. (2004). Persistence of cccDNA during the natural history of chronic hepatitis B and decline during adefovir dipivoxil therapy. Gastroenterology 126, 1750-1758. doi: 10.1053/j.gastro.2004.03.018

Werr, M., and Prange, R. (1998). Role for calnexin and N-linked glycosylation in the assembly and secretion of hepatitis B virus middle envelope protein particles. J. Virol. 72, 778-782.

WHO (2017). Global hepatitis report, 2017. Geneva: World Health Organization.

Wu, T. T., Coates, L., Aldrich, C. E., Summers, J., and Mason, W. S. (1990). In hepatocytes infected with duck hepatitis B virus, the template for viral RNA synthesis is amplified by an intracellular pathway. Virology 175, 255-261.

Wu, Y. H., Ai, X., Liu, F. Y., Liang, H. F., Zhang, B. X., and Chen, X. P. (2016). c-Jun N-terminal kinase inhibitor favors transforming growth factorbeta to antagonize hepatitis $\mathrm{B}$ virus $\mathrm{X}$ protein-induced cell growth promotion in hepatocellular carcinoma. Mol. Med. Rep. 13, 1345-1352. doi: 10.3892/mmr. 2015.4644

Xia, L., Wang, S., Zhang, H., Yang, Y., Wei, J., Shi, Y., et al. (2020). The HBx and $\mathrm{HBC}$ of hepatitis B virus can influence Id1 and Id 3 by reducing their transcription and stability. Virus Res. 284:197973. doi: 10.1016/j.virusres.2020. 197973

Xian, L., Zhao, J., Wang, J., Fang, Z., Peng, B., Wang, W., et al. (2010). p53 Promotes proteasome-dependent degradation of oncogenic protein HBx by transcription of MDM2. Mol. Biol. Rep. 37, 2935-2940. doi: 10.1007/s11033-009-9855-1

Xiang, A., Ren, F., Lei, X., Zhang, J., Guo, R., Lu, Z., et al. (2015). The hepatitis $B$ virus (HBV) core protein enhances the transcription activation of CRE via the CRE/CREB/CBP pathway. Antiviral. Res. 120, 7-15. doi: 10.1016/j.antiviral. 2015.04.013

Xu, F., Song, H., Xiao, Q., Li, N., Zhang, H., Cheng, G., et al. (2019). Type III interferon-induced CBFbeta inhibits HBV replication by hijacking HBx. Cell Mol. Immunol. 16, 357-366. doi: 10.1038/s41423-0180006-2

Xu, L., Wu, Z., Tan, S., Wang, Z., Lin, Q., Li, X., et al. (2018). Tumor suppressor ZHX2 restricts hepatitis B virus replication via epigenetic and nonepigenetic manners. Antiviral. Res. 153, 114-123. doi: 10.1016/j.antiviral.2018. 03.008

Yan, H., Peng, B., He, W., Zhong, G., Qi, Y., Ren, B., et al. (2013). Molecular determinants of hepatitis B and D virus entry restriction in mouse sodium taurocholate cotransporting polypeptide. J. Virol. 87, 7977-7991. doi: 10.1128/ JVI.03540-12

Yan, H., Zhong, G., Xu, G., He, W., Jing, Z., Gao, Z., et al. (2012). Sodium taurocholate cotransporting polypeptide is a functional receptor for human hepatitis B and D virus. Elife 1:e00049. doi: 10.7554/eLife.00049 
Yan, H., Zhong, G., Xu, G., He, W., Jing, Z., Gao, Z., et al. (2014). Sodium taurocholate cotransporting polypeptide is a functional receptor for human hepatitis B and D virus. Elife 3:49.

Yang, C. C., Huang, E. Y., Li, H. C., Su, P. Y., and Shih, C. (2014). Nuclear export of human hepatitis B virus core protein and pregenomic RNA depends on the cellular NXF1-p15 machinery. PLoS One 9:e106683. doi: 10.1371/journal.pone. 0106683

Yang, S. T., Yen, C. J., Lai, C. H., Lin, Y. J., Chang, K. C., Lee, J. C., et al. (2013). SUMOylated CPAP is required for IKK-mediated NF-kappaB activation and enhances HBx-induced NF-kappaB signaling in HCC. J. Hepatol. 58, 1157-1164. doi: 10.1016/j.jhep.2013.01.025

Yao, J. H., Liu, Z. J., Yi, J. H., Wang, J., and Liu, Y. N. (2018). Hepatitis B Virus X Protein Upregulates Intracellular Calcium Signaling by Binding C-terminal of Orail Protein. Curr. Med. Sci. 38, 26-34. doi: 10.1007/s11596-018-1843-Z

Yoo, Y. G., and Lee, M. O. (2004). Hepatitis B virus X protein induces expression of Fas ligand gene through enhancing transcriptional activity of early growth response factor. J. Biol. Chem. 279, 36242-36249. doi: 10.1074/jbc.M401290200

Yoo, Y. G., Na, T. Y., Seo, H. W., Seong, J. K., Park, C. K., Shin, Y. K., et al. (2008). Hepatitis B virus X protein induces the expression of MTA1 and HDAC1, which enhances hypoxia signaling in hepatocellular carcinoma cells. Oncogene 27, 3405-3413. doi: 10.1038/sj.onc. 1211000

You, D. G., Cho, Y. Y., Lee, H. R., Lee, J. H., Yu, S. J., Yoon, J. H., et al. (2019). Hepatitis B virus $\mathrm{X}$ protein induces size-selective membrane permeabilization through interaction with cardiolipin. Biochim. Biophys. Acta Biomembr. 1861, 729-737. doi: 10.1016/j.bbamem.2019.01.006

Yu, H. B., Cheng, S. T., Ren, F., Chen, Y., Shi, X. F., Wong, V. K. W., et al. (2021). SIRT7 restricts HBV transcription and replication through catalyzing desuccinylation of histone $\mathrm{H} 3$ associated with cccDNA minichromosome. Clin. Sci. 135, 1505-1522. doi: 10.1042/CS20210392

Yu, X., and Mertz, J. E. (2003). Distinct modes of regulation of transcription of hepatitis B virus by the nuclear receptors HNF4alpha and COUP-TF1. J. Virol. 77, 2489-2499.

Yu, Y., He, Z., Cao, Y., Tang, H., and Huang, F. (2016). TAGLN2, a novel regulator involved in Hepatitis B virus transcription and replication. Biochem. Biophys. Res. Commun. 477, 1051-1058. doi: 10.1016/j.bbrc.2016.07.034

Yuan, Y., Tian, C., Gong, Q., Shang, L., Zhang, Y., Jin, C., et al. (2015). Interactome map reveals phospholipid scramblase 1 as a novel regulator of hepatitis $B$ virus x protein. J. Proteome Res. 14, 154-163. doi: 10.1021/pr500943x

Zajakina, A., Bruvere, R., and Kozlovska, T. (2014). A Semliki Forest virus expression system as a model for investigating the nuclear import and export of hepatitis B virus nucleocapsid protein. Acta Virol. 58, 173-179. doi: 10.4149/ av_2014_02_173

Zhang, J. L., Zhao, W. G., Wu, K. L., Wang, K., Zhang, X., Gu, C. F., et al. (2005). Human hepatitis B virus X protein promotes cell proliferation and inhibits cell apoptosis through interacting with a serine protease Hepsin. Arch. Virol. 150, 721-741. doi: 10.1007/s00705-004-0446-0

Zhang, S., Lin, R., Zhou, Z., Wen, S., Lin, L., Chen, S., et al. (2006). Macrophage migration inhibitory factor interacts with $\mathrm{HBx}$ and inhibits its apoptotic activity. Biochem. Biophys. Res. Commun. 342, 671-679. doi: 10.1016/j.bbrc. 2006.01.180

Zhang, T., Xie, N., He, W., Liu, R., Lei, Y., Chen, Y., et al. (2013). An integrated proteomics and bioinformatics analyses of hepatitis $\mathrm{B}$ virus $\mathrm{X}$ interacting proteins and identification of a novel interactor apoA-I. J. Proteomics 84, 92-105. doi: 10.1016/j.jprot.2013.03.028

Zhang, T., Zhang, J., You, X., Liu, Q., Du, Y., Gao, Y., et al. (2012). Hepatitis $\mathrm{B}$ virus $\mathrm{X}$ protein modulates oncogene Yes-associated protein by CREB to promote growth of hepatoma cells. Hepatology 56, 2051-2059. doi: 10.1002/hep. 25899

Zhang, W., Chen, J., Wu, M., Zhang, X., Zhang, M., Yue, L., et al. (2017). PRMT5 restricts hepatitis $\mathrm{B}$ virus replication through epigenetic repression of covalently closed circular DNA transcription and interference with pregenomic RNA encapsidation. Hepatology 66, 398-415. doi: 10.1002/hep.29133

Zhang, W., Zhang, X., Tian, C., Wang, T., Sarkis, P. T., Fang, Y., et al. (2008). Cytidine deaminase APOBEC3B interacts with heterogeneous nuclear ribonucleoprotein $\mathrm{K}$ and suppresses hepatitis B virus expression. Cell Microbiol. 10, 112-121. doi: 10.1111/j.1462-5822.2007.01020.x
Zhang, Y. Y., Zhang, B. H., Theele, D., Litwin, S., Toll, E., and Summers, J. (2003). Single-cell analysis of covalently closed circular DNA copy numbers in a hepadnavirus-infected liver. Proc. Natl. Acad. Sci. U S A 100, 12372-12377. doi: 10.1073/pnas.2033898100

Zhang, Y., He, S., Guo, J. J., Peng, H., Fan, J. H., and Li, Q. L. (2017). Retinoid X Receptor alpha-Dependent HBV Minichromosome Remodeling and Viral Replication. Ann. Hepatol. 16, 501-509. doi: 10.5604/01.3001.0010.0275

Zhang, Y., Liu, J., Liu, H., He, Y., Yi, R., Niu, Y., et al. (2015). Comparative study of the different activities of hepatitis $B$ virus whole-X protein and $\mathrm{HBx}$ in hepatocarcinogenesis by proteomics and bioinformatics analysis. Arch Virol 160, 1645-1656. doi: 10.1007/s00705-015-2421-3

Zhang, Y., Mao, R., Yan, R., Cai, D., Zhang, Y., Zhu, H., et al. (2014). Transcription of hepatitis B virus covalently closed circular DNA is regulated by CpG methylation during chronic infection. PLoS One 9:e110442. doi: 10.1371/ journal.pone.0110442

Zhang, Z., Torii, N., Furusaka, A., Malayaman, N., Hu, Z., and Liang, T. J. (2000). Structural and functional characterization of interaction between hepatitis B virus X protein and the proteasome complex. J. Biol. Chem. 275, 15157-15165. doi: 10.1074/jbc.M910378199

Zhao, D., Wang, X., Lou, G., Peng, G., Li, J., Zhu, H., et al. (2010). APOBEC3G directly binds Hepatitis B virus core protein in cell and cell free systems. Virus Res. 151, 213-219. doi: 10.1016/j.virusres.2010.05.009

Zheng, D. L., Zhang, L., Cheng, N., Xu, X., Deng, Q., Teng, X. M., et al. (2009). Epigenetic modification induced by hepatitis $\mathrm{B}$ virus $\mathrm{X}$ protein via interaction with de novo DNA methyltransferase DNMT3A. J. Hepatol. 50, 377-387. doi: 10.1016/j.jhep.2008.10.019

Zheng, Y., Chen, W. L., Ma, W. L., Chang, C., and Ou, J. H. (2007). Enhancement of gene transactivation activity of androgen receptor by hepatitis B virus X protein. Virology 363, 454-461. doi: 10.1016/j.virol.2007.01.040:10.1016/j.virol.2007.01.040

Zheng, Y., Ming, P., Zhu, C., Si, Y., Xu, S., Chen, A., et al. (2019). Hepatitis B virus $\mathrm{X}$ protein-induced $\mathrm{SH} 2$ domain-containing 5(SH2D5) expression promotes hepatoma cell growth via an SH2D5-transketolase interaction. J. Biol. Chem. 2019:5739. doi: 10.1074/jbc.RA118.005739

Zhou, D. X., and Yen, T. S. (1991). The ubiquitous transcription factor Oct-1 and the liver-specific factor HNF-1 are both required to activate transcription of a hepatitis B virus promoter. Mol. Cell Biol. 11, 1353-1359.

Zhou, J., Tan, T., Tian, Y., Zheng, B., Ou, J. H., Huang, E. J., et al. (2011). Kruppellike factor 15 activates hepatitis $\mathrm{B}$ virus gene expression and replication. Hepatology 54, 109-121. doi: 10.1002/hep.24362

Zlotnick, A., Venkatakrishnan, B., Tan, Z., Lewellyn, E., Turner, W., and Francis, S. (2015). Core protein: A pleiotropic keystone in the HBV lifecycle. Antiviral. Res. 121, 82-93. doi: 10.1016/j.antiviral.2015.06.020

Zou, L. Y., Zheng, B. Y., Fang, X. F., Li, D., Huang, Y. H., Chen, Z. X., et al. (2015). HBx co-localizes with COXIII in HL-7702 cells to upregulate mitochondrial function and ROS generation. Oncol. Rep. 33, 2461-2467. doi: 10.3892/or.2015. 3852

Conflict of Interest: EVD, FP, LV, and BS are employees of Janssen Research and Development and may be Johnson \& Johnson stockholders. JV was employed at Janssen Research and Development at the time of the work and drafting of the manuscript and may be Johnson \& Johnson stockholder.

Publisher's Note: All claims expressed in this article are solely those of the authors and do not necessarily represent those of their affiliated organizations, or those of the publisher, the editors and the reviewers. Any product that may be evaluated in this article, or claim that may be made by its manufacturer, is not guaranteed or endorsed by the publisher.

Copyright (c) 2021 Van Damme, Vanhove, Severyn, Verschueren and Pauwels. This is an open-access article distributed under the terms of the Creative Commons Attribution License (CC BY). The use, distribution or reproduction in other forums is permitted, provided the original author(s) and the copyright owner(s) are credited and that the original publication in this journal is cited, in accordance with accepted academic practice. No use, distribution or reproduction is permitted which does not comply with these terms. 